\title{
Beach macro-litter monitoring on southern Baltic beaches: results, experiences and recommendations
}

\author{
Gerald Schernewski $^{1,2}$ (D) Arunas Balciunas ${ }^{2,1} \cdot$ Dennis Gräwe ${ }^{3} \cdot$ Ulf Gräwe $^{1} \cdot$ \\ Kristina Klesse $^{4} \cdot$ Marcus Schulz $^{5}$ - Sylvie Wesnigk ${ }^{1}$ - David Fleet ${ }^{6} \cdot$ Mirco Haseler $^{1}$. \\ Nils Möllman ${ }^{7} \cdot$ Stefanie Werner $^{8}$
}

Received: 4 July 2016 /Revised: 21 November 2016/Accepted: 19 December 2016 / Published online: 24 February 2017

(C) The Author(s) 2017. This article is published with open access at Springerlink.com

\begin{abstract}
Major objectives were to provide a comprehensive dataset on beach macro-litter for parts of the southern Baltic Sea and to analyse if the methodology is fully applicable and a suitable monitoring method in the Baltic. We carried out a regular macro litter beach monitoring (OSPAR methodology, 4 time a year) on 35 beaches along the German and Lithuanian Baltic coast over $2-5$ years. Additional experiments addressed the subjectivity of the field surveys and spatio-temporal variability on different scales. We observed no seasonality of the data and a monthly compared to a 3-monthly sampling resulted in 3 times higher annual item numbers. Along the Lithuanian coast, the average number of items per survey varied between 138 and 340 and along the German Baltic
\end{abstract}

Gerald Schernewski

gerald.schernewski@io-warnemuende.de

1 Leibniz-Institute for Baltic Sea Research, Seestrasse 15, D-18119 Rostock, Germany

2 Marine Science and Technology Center, Klaipeda University, H. Manto 84, LT-92294 Klaipeda, Lithuania

3 State Agency for Environment, Nature Conservation and Geology Mecklenburg-Vorpommern (LUNG), Goldberger Strasse 12, D-18273 Güstrow, Germany

4 EUCC - The Coastal Union Germany e.V, Seestraße 15, D-18119 Rostock-Warnemünde, Germany

5 AquaEcology GmbH \& Co. KG, Marie-Curie-Str.1, D-26129 Oldenburg, Germany

6 The Schleswig-Holstein Agency for Coastal Defence, National Park and Marine Conservation, National Park Authority, Schlossgarten 1, D-25832 Tönning, Germany

7 NABU, Charitéstraße 3, 10117 Berlin, Germany

8 German Environmental Agency (UBA), Wörlitzer Platz 1, D-06844 Dessau-Rosslau, Germany coast between 7 and 404, with a median value of 47 . All data showed a very high spatio-temporal variability. Using the Matrix Scoring Technique we assessed beach litter sources. With 50\% tourism and recreation was the most important source. 3D-transport simulations helped to explain the minor role of shipping as a source and, compared to the North Sea, the low numbers of items on German Baltic beaches. Floating litter had a short duration time in the western Baltic Sea and offshore drift dominated. Further, the common regular beach cleanings reduced the potential for local litter accumulation and translocation. We suggest a monitoring system on 14 Baltic beaches in Germany and 2 in Lithuania and provide cost calculations. The analysis of macro-litter in cormorant nesting material and the search for beached dead animals did not show any result. We can conclude that the macro-litter beach monitoring method is less suitable for Baltic beaches and should only serve as a complementary method in combination with others.

Keywords Marine strategy framework directive $\cdot$ Marine policy $\cdot$ Cormorant $\cdot$ Model simulation $\cdot$ Cluster analysis

\section{Introduction}

The pollution of beaches with macro-litter, the size fraction above $2.5 \mathrm{~cm}$, is well known and associated problems for the coastal and marine fauna are well documented for many regions world-wide: Litter abundancy in Monterey Bay, California, ranged from 0.03 to 17.1 items $\mathrm{m}^{-2}$ (Rosevelt et al. 2013); on remote Alphonse Island, Seychelles, during 6 weeks a total of 4743 items were found on $1 \mathrm{~km}$ beach (Duhec et al. 2015); on 10 beaches of the Turkish Western Black Sea, beach litter densities varied between 0.01 and 5.0 items $\mathrm{m}^{-2}$ (Topçu et al. 2013); quantities of marine debris at 
20 beaches in Korea were $481( \pm 268) / 100$ m per survey; on recreational beaches in Mumbai, India, even an average of 69 items $/ \mathrm{m}^{2}$ has been observed (Jayasiri et al. 2013). The examples show that marine litter at coasts is a global problem and that beach macro-litter monitoring is commonly applied. However, it also indicates that very different methods and units are used that hardly allow comparisons.

UNEP/IOC published the 'Guidance on Survey and Monitoring of Marine Litter' (UNEP/IOC 2009), NOAA provided comprehensive 'Recommendations for Monitoring Debris Trends' (Lippiatt et al. 2013) and OSPAR contributed the 'Guideline for Monitoring Marine Litter on the Beaches' (OSPAR 2010). For the Baltic Sea region, the HELCOM (2008) Recommendation 29/2 contains the HELCOM Guidelines on beach litter. In practice, the OSPAR monitoring guidelines are largely used in Europe and ensure that recent data is comparable: On the Galician coast, Spain, the average annual value of litter items at beaches were $1016 \pm 633 / 100 \mathrm{~m}$ or 504/100 m per survey (Gago et al. 2014); on four beaches in the south-eastern North Sea, mean abundances between 105 and 435 items $/ 100 \mathrm{~m}$ per survey were found (Schulz et al. 2015a); in the central Baltic (Finland, Sweden, Latvia, Estonia) an average number of 237 litter items/100 m per survey has been found on urban beaches, compared to 76 litter items/100 $\mathrm{m}$ at rural beaches. Cigarette butts $(49 / 100 \mathrm{~m}$ in rural areas, and 302/100 $\mathrm{m}$ on urban beaches) are not included in these numbers and have to be added to get a full impression of the pollution (MARLIN 2013). In a preliminary study, Balčiūnas and Blažauskas (2014) collected between 138 and 340 items/100 m (average 222) on beaches in Lithuania.

The European Marine Strategy Framework Directive (MSFD 2008/56/EC) contains a list of descriptors for a good status of the marine environment that shall be achieved until 2020. Among them 'Properties and quantities of marine litter do not cause harm to the coastal and marine environment. As consequence, it is necessary to assess 'Trends in the amount of litter washed ashore and/or deposited on coastlines, including analysis of its composition, spatial distribution and, where possible, source'. This requires a joint, harmonized monitoring strategy, which is outlined in JRC (2013) 'Guidance on Monitoring of Marine Litter in European Seas'. It adapts and further develops OSPAR (2010), e.g. by providing a modified item master list.

Objectives of this study were to a) provide a comprehensive dataset on beach macro-litter for parts of the southern Baltic Sea; b) analyse to what extend the OSPAR methodology is fully applicable and suitable for the MSFD; c) test if a beach macro-litter monitoring would fulfil the requirements outlined in JRC (2013), namely to establish targets, allows an on-going assessment of the environmental status within the MSFD, is compatible, coherent, consistent and comparable; d) discuss if macro-litter monitoring could serve as basis for the development of management, control and enforcement measures and allows the effectiveness of mitigation strategies to be measured; e) exemplary investigate possible threats for biota and ecosystems d) suggest a cost-effective and representative monitoring strategy for the German and Lithuanian Baltic coast based on an initially large number of surveyed beaches and statistical analysis.

\section{Methods and study sites}

\section{Field sampling}

In order to create a sufficient database for statistical analyses, to serve as a basis for an monitoring beach selection process and to fulfil the requirements of the MSFD, a regular macrolitter beach monitoring survey, carried out by experts and trained volunteers, took place on 31 beaches along the German Baltic coast and on 4 beaches in Lithuania (Fig. 7). For the German Baltic coast, over a period of 2-5 years (2011-2015), a repetition of survey at each individual beach varied from 5 times (Hohe Düne, Lubmin, Ludwigsburg, Usedom and Warnemünde) to 14 times (Binz, Fehmarn Grüner Brink, Fehmarn Wallnau, Göhren and Vilm). The surveys on all Lithuanian Baltic Sea coast were carried out four times a year (seasonal) for a period of two years (2013-2014).

The selection of survey beaches followed the criteria defined in OSPAR (2010). The beaches had to be composed of sand or gravel and exposed to the open sea; accessible to surveyors all year round; have a minimum length of at least several $100 \mathrm{~m}$; be free of buildings all year round and not subject to any other litter collection activities (beach cleaning). In addition, logistical aspects like the availability of local volunteers and a sufficient geographical coverage determined the choice.

The survey methodology followed guidelines and protocols provided by OSPAR (2010): Two persons carried out the data collection on fixed $100 \mathrm{~m}$ beach stretches that covered the whole area between sea front and back of the beach. The exact location and stretch of beaches were documented using GPS. The survey was carried out 4 times a year (winter, spring, summer and autumn). All visible to the naked eye items found during the survey were determined and entered into provided survey forms. The OSPAR photo guide assisted the identification and classification of litter items. The majority of collected items belonged to the size class above $2.5 \mathrm{~cm}$ (macro-litter). However, smaller meso-litter particles (0.5$2.5 \mathrm{~cm}$ ), e.g. cigarette butts, were partly included, as well.

To assess the subjectivity of the field monitoring methodology (item abundance dependency on the surveyor and field sampling approach) assessment, additional four comparative test samplings were carried out:

In the first experiment, the sampling approach was tested in Kägsdorf (Germany, Fig.1). Surveyors were divided into 3 
Fig. 1 Location of the study areas and examples of long-term monitoring beaches. The location of the beaches are indicated in Fig. 6
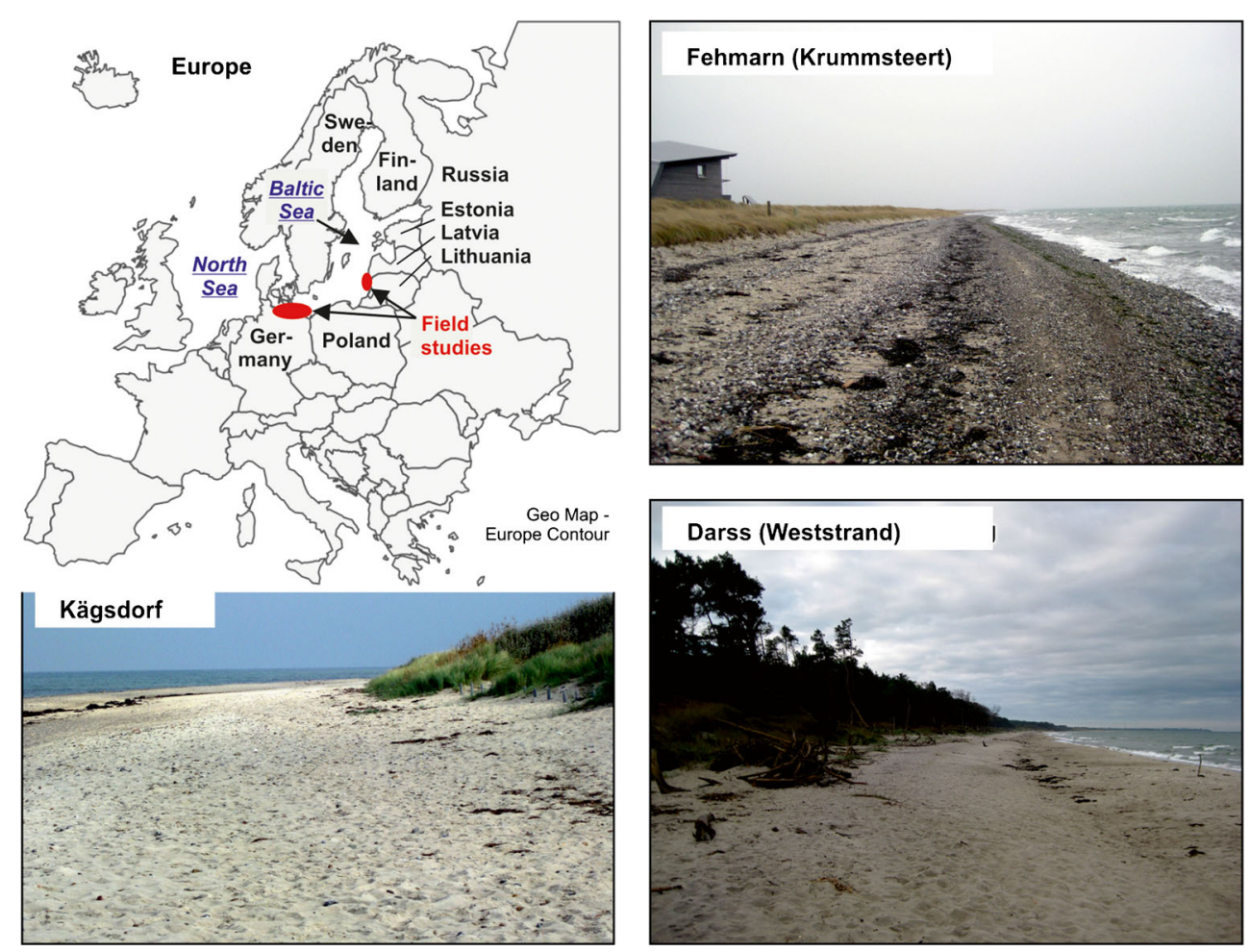

groups with 2 people each and had to execute three different variations of $100 \mathrm{~m}$ beach monitoring approaches. The surveyors had fully overlapping areas and each person counted items independently, without picking up. In the first variation (Transect 1), two persons walked parallel from the shoreline to the start of dune vegetation and counted items. In the second variation (Transect 2), two persons walked parallel from the start of dune vegetation to shoreline. In a third variation (Transect 3), one group member started at the shoreline and the other started at the start of dune vegetation.

In the second experiment, the item abundance dependency to visual and picking up techniques was tested in Giruliai (Lithuania, north of Klaipeda, Fig. 7). The surveyors were divided into 3 groups with 2 people each and had to execute two different survey techniques for three separate $100 \mathrm{~m}$ beach transects. First technique was to perform a visual counting while walking parallel form the shoreline to the start of dune vegetation and a second technique was to pick up all items while walking parallel from shore line to the start of dune vegetation.

In the third experiment, the accuracy of picking up technique was tested on the Curonian Spit, Lithuania (Fig.4). Surveyors were divided into five groups with 2 people each and a defined starting transect. Every group had to perform two surveys while walking parallel from shoreline to the start of vegetation. For the first survey, groups had to pick up all found items on their starting transect and for the second survey groups would repeat the survey on a neighbouring transect to pick-up unspotted or remained items.
In the fourth experiment, the necessity of a higher temporal sampling frequency as well as replicas (surveys on two neighbouring transects) was tested in Kägsdorf beach, Germany (Fig. 5). Five neighbouring $100 \mathrm{~m}$ transects were defined, receding east from the parking place, and monitored. Closest to the parking place transects (T1 and T2) were sampled 4 times a year (summer, autumn, winter, spring) and the remaining 3 transects (T3, T4 and T5) were surveyed on a monthly basis between July 2014 and April 2015.

\section{Data processing and statistical analyses}

Prior to cluster analyses, a non-parametric analysis of variance (ANOVA, Kruskal-Wallis-test) was calculated, to test for significant differences between the first and second survey ever carried out at each beach. Total abundances of the first and second survey were used as input data $(n=56)$. Hypothesis was that the first surveys delivers significantly higher abundances than the following survey. Litter always was removed during surveys, but the first survey reflects the long-term accumulation without beach cleaning. If this hypothesis holds, results of first surveys cannot be considered as input data for cluster analyses.

For other statistical analyses, only beaches with more than 4 surveys were considered, to ensure sufficient statistical reliability. For each of these beaches, mean values and standard deviations of abundances of items, general categories and total beach litter were calculated. Based on mean abundances, the ten most abundant items per beach were identified. Items, 
which were at least during 10 surveys among the top ten items per sampling location (beach), were selected for subsequent cluster analyses. It ensured that the numbers of ties and zero values in the input data, potentially compromising cluster analyses, were low. The mean values of 13 items (including six unidentifiable fragments) constituted a beach litter profile for each beach, which were used as input data for cluster analyses. It was doubtful whether fragment items would be beneficial for the analysis because of unknown sources and input pathways. Therefore, in additional cluster analyses, only the seven identifiable items of beach litter were used as input data. The alternative approach, to carry out cluster analysis with all items that have a high likelihood to result from a certain emission source was not possible, because of too low abundance numbers.

Cluster analyses comprised three different grouping algorithms. In a first step, beaches were clustered applying single linkage with Euclidean distance as measure of proximity, in order to identify outlying beaches, which had to be removed from subsequent statistical analyses. In a second step, the Ward method was applied together with Euclidean distance as measure of proximity, in order to cluster the remaining beaches according to their degree of pollution with beach litter. Finally, complete linkage was applied together with 1 - Pearson correlation coefficient as measure of proximity, to group beaches to clusters of similar beach litter profiles. It was expected to group beaches according to similar sources of beach litter, such as tourism, shipping and riverine discharge.

\section{Matrix scoring technique for beach litter sources}

We adapted and used the methodology of Tudor and Williams (2004). It combines a percentage allocation method with the cross tabulation probability scoring method, developed by Whiting (1998) into the 'Matrix Scoring Technique'. For the Baltic Sea, all litter items found at the beach, were allocated to defined categories, like paper, artificial polymers, as well as certain subcategories, like cigarette butts or plastic bags. In a second step, the likelihood was estimated that the category results from five considered sources for marine litter: tourism (beach users and all kind of recreational activities on the beach and in the surf zone); sewage related debris; shipping; offshore installations and fishing related debris. Many items could not be attributed to one source alone, therefore a likelihood was defined that items of a category stem from each of the 5 sources: very unlikely (score 0 ), unlikely (1), possible (2), likely (3) and very likely (4) (Fig. 2). The scoring was carried out based on our knowledge obtained during the field sampling. The percentage that an item originates from a source is the result of the score per source multiplied with the total percentage of items found per particular category, divided by the total amount of scores per particular category. For the North Sea sampling locations, the same system was applied to allow a direct comparison of the method with the Baltic Sea and to visualize differences between both systems. $58 \%$ of all item categories were suitable for and included in this analysis. For details see Tudor and Williams (2004) and Appendix 1.

\section{D- transport modelling}

To get an impression of the spatio-temporal transport of marine litter and their accumulation at German beaches, a numerical modelling system was employed capable of tracking the fate of hypothetical litter particles. It combined a 3D flow model, the General Estuarine Transport Model (GETM) (Burchard and Bolding 2002), with a 2D particle-tracking model. The entire western Baltic Sea was discretised horizontally with a dense grid of $600 \mathrm{~m}$ and with 50 vertical layers (flexible bottom surface-following layers) (Klingbeil et al. 2014; Gräwe et al. 2015a). The atmospheric forcing was derived from the operational model of the German Weather Service with a spatial resolution of $7 \mathrm{~km}$ and a temporal resolution of $3 \mathrm{~h}$. Input parameters were air temperature, humidity, cloud cover, air pressure, precipitation and wind fields
Fig. 2 Matrix Scoring Technique after Tudor and Williams (2004) for the determination of the likelihood that macro-litter items come from one of the five considered potential pollution sources

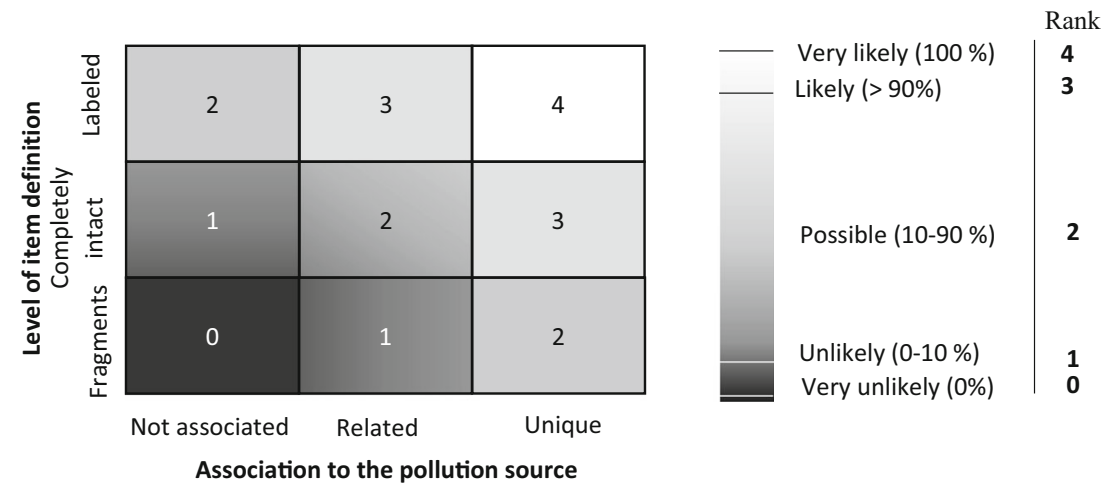


taken at $10 \mathrm{~m}$ above mean sea level. In addition, data from a large scale model covering the North Sea/Baltic Sea was used to force the Western Baltic Sea model (Gräwe et al. 2015b).

Because of data availability, the model simulations covered the years 2003 to 2009, providing seven years of forcing for the particle-tracking tool. The data coverage of 7 years helped to ensure a valid statistics of the model outcome. In this study, we restricted ourselves to litter particles that have a density close to water and float with the water surface layer. Therefore, only the surface velocity fields of the hydrodynamic model was extracted to drive the particle-tracking model. The stored velocity fields had a time step of one hour to resolve even high frequent motions like inertial motions or tidal effects.

The particle tracking model used in this study solved the equation of motion for non-buoyant particles (Gräwe and Wolff 2010). The individual particles were integrated with a time step of $60 \mathrm{~s}$ through the hourly external velocity fields. The linearly interpolation in time and space to get the required velocity information for the actual position of the particle, was used. To account for the beach accumulation of the macrolitter particles, the assumption was made, that particles were washed ashore as soon as they entered the wave surf zone. The surf zone was represented by the nearest grid cells to the coastline. Particles were counted in this grid cell and removed from the computation to avoid double counting. The alternative introduction of a beaching probability would not have altered the results. For sure, the total number of coastal hits would be reduced, nevertheless, the spatial pattern would have remained the same.

Two selected forecast scenarios concerning the transport of floating litter were considered here, corresponding to two hypothetical particle emission sources a) sea-based emission along the main traffic shipping routes in the Baltic Sea (lost items originating from ships of any kind) and b) land-based emission coming from two selected coastal resorts (Warnemünde and Kühlungsborn).

In the case of sea-based emissions, the main focus was to study the overall litter accumulation in the western Baltic Sea. Accordingly, the density of litter release cells was chosen corresponding to the frequency of ship traffic. The main traffic on the Baltic Sea passes the east-west route including Kadet Fairway. It amounted to 52,000 ships in 2010 and 64,000 ships in 2008 (Bundesregierung 2011). Other important shipping routes were the ferry connections. With approximately 11,000 movements per year and route, a six times lower rate of litter emission was assumed for each ferry line as compared to the east-west route. In the simulation, 100 hypothetical particles were released per $2 \mathrm{~km}$ cell and day. The number of particles washed ashore on the complete coastline of the western Baltic Sea was computed per cell and month. The litter distribution for individual months for time period of seven years (2003-2009) and the corresponding annual average was determined (Fig. 9, top). The emission cell size and the number of emitted particles were largely limited by the computational capacity.

The transport and behaviour of land-based emission were exemplary simulated for two important tourism resorts, Warnemünde and Kühlungsborn. We assumed that emissions from the beach into the water take place only during bathing season from May to September. 13 particle emission cells covered the costal stretch of Kühlungsborn and ten cells the beach of Warnemünde. A total 1000 particles were distributed evenly between these cells. Their transport was simulated over 3 days. 25 model simulations were carried out for each of the two resorts. It is important to note that there is no reliable information on the ratio of litter amounts originating from sea-based and land-based sources. Therefore, the simulations only provided qualitative results. No quantitative comparison between sea-based and land-based litter release is possible. The entire post processing was done with MathWorks ${ }^{\circledR} M A T L A B$ and the visualisation with ESRI ArcGis.

\section{Analysis of cormorant nesting material}

During macro-litter sampling, the surveyors were instruced to collect dead animals at the beach and provide them for laboratory analysis. Further, an analysis of nesting material of a Great Cormorant (Phalacrocorax carbo sinensis) was carried out to get insight into the impacts of marine litter on animals.

The exemplary study of cormorant nests was conducted on the 14 ha large island Heuwiese in November 2011. It is located in the west of the island of Rügen, Germany. As an uninhabited island this location is well-suited for the monitoring because all litter found on this island, on the shores or in bird nests, can only be of sea-based origin.

A ground-breeding Great Cormorant colony of 500 to 1000 nests exists since 1990 on the island. In 2011, 400 pairs of Great cormorants hatched in three sub-colonies on the island: In the west, the east and the principal sub-colony (Fig. 11). Nests of the principal sub-colony are older than those of the western and eastern sub-colonies. In 2011, the latter were not older than 2 years because of winter floods that had destroyed previous nests. This bird species uses nest material originating from the near surroundings. Basically, nests consisted of grass-leaved orache (Artiplex littoralis), grass, feathers and items found accidentally, like marine litter. Great Cormorants re-used old nests and expanded them in height by about $10 \mathrm{~cm}$ every year.

A total of $10 \%$ of all nests on the island $(N=40)$ were studied. The investigated nests were selected as randomly 
chosen blocks. 20 nests each were picked from the centrally located principal colony and from the peripheral western colony. For each nest, size and height were determined. Afterwards the nests were taken apart layer by layer and the abundance of marine litter was recorded, collected and analysed in the laboratory. The litter was air-dried and cleaned from plants and soil. Afterwards, the items were weighted and categorised. Litter types and amounts between young and old nests were compared.

Additionally, the responsible ranger for the reserve on the Heuwiese completed a list providing information on the presence of OSPAR litter categories that he had observed during long-lasting work on the island. The abundance of categories was classified with numbers ranging from 0 for absence to 3 for high abundance. For comparison reasons, the same classification was performed for the beach of Bug, where a $3 \mathrm{~km}$ long stretch was investigated by another ranger. Due to its close proximity to Heuwiese, it is likely that Bug was influenced by the same litter source.

\section{Results and discussion}

\section{Assessment of the subjectivity of the field monitoring methodology}

First experiment where a sampling approach was tested in Kägsdorf revealed that there are no systematic differences between single persons and a team carrying out the survey (Fig. 3a). However, differences in the number of items recorded varied from $5 \%$ to $21 \%$. This clearly indicates that the methodology includes a significant uncertainty and that the surveyors play an important role. A thorough training is imperative. Weather and light conditions may also increase uncertainty. The spatial definition of the beach (backside boundary) turned out to be largely reproducible and did not affect results significantly.

In the second experiment, three groups carried out three $100 \mathrm{~m}$ surveys first counting without picking items up and afterwards on another transect with picking up items. In general the number of items increased by $32-75 \%$ when switching from mere observation to picking-up particles (Fig. 3b). One explanation is that when bending down to pick up particles, other especially small particles are additionally spotted. As consequence, the total number of items found during a survey increased. It shows that as soon as particles are picked up, the quality and reliability of the data increases significantly. This confirms the recommendation by JRC (2010) and the OSPAR Guideline (2010) and indicates that picking-up particles is a necessity.

In the third experiment, a previously surveyed and cleaned beach was contolled by another surveyor team. In average between 16 and 27 particle or about $10 \%$ were additionally
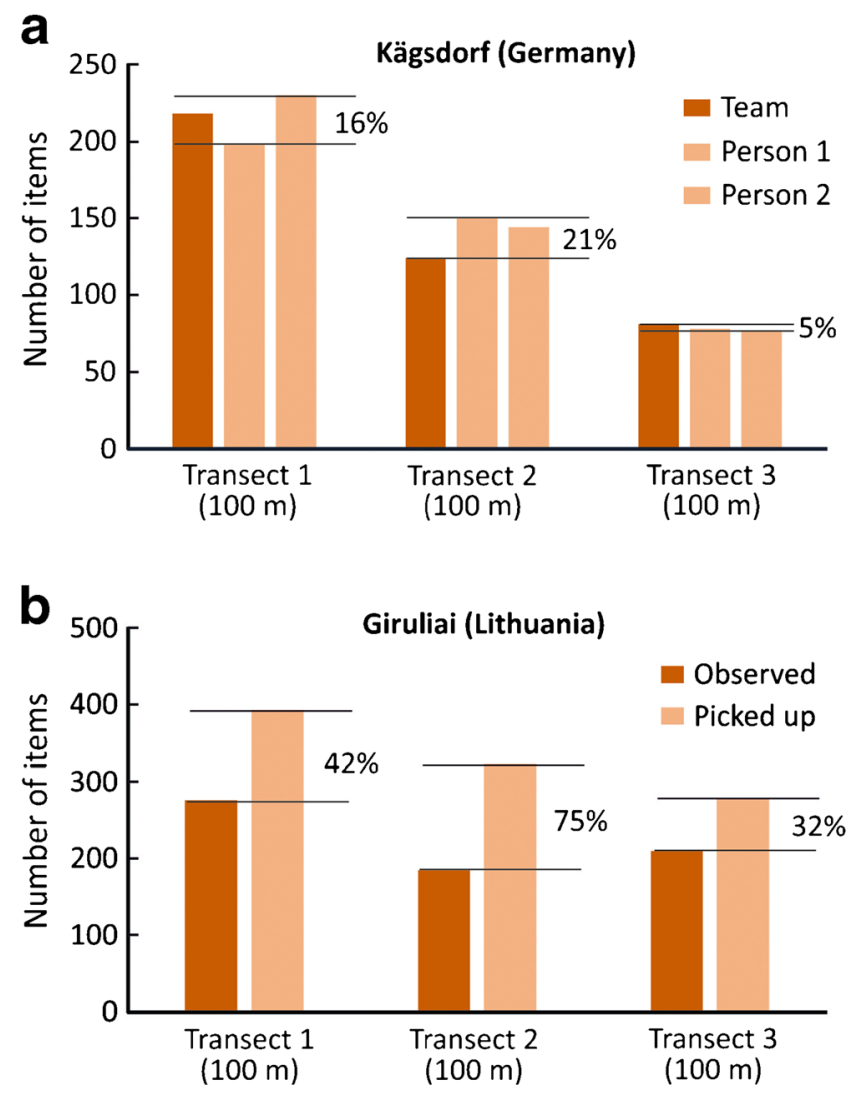

Fig. 3 a Surveys at Kägsdorf in Germany were two single persons and a team carried out surveys of the same transect without pick-up items. b Survey at Giruliai beach in Lithuania where the first team counted items without picking-up and a second team carried out a control survey picking-up items

found during the second control survey (Fig. 4). Taking into account different surveyors, weather and light conditions, we estimate an error per survey in the range of at least $+/-15 \%$. To reduce uncertainty, it is important to ensure that always the same surveyor carries out the survey.

\section{Spatio-temporal variability}

The survey of 5 transects on the Curonian Spit (Neringa Municipality), Lithuania was carried out on a remote nature protected beach, with very rare access by the public. Idea was to investigate small-scale spatial variability on a larger homogeneous coastline, where all transects show a very similar structure, exposition, beach width and where no obvious pollution gradients could be expected. On most monitored Lithuanian beaches (e.g. Nemirseta, Karkle, Klaipeda or Palanga) cigarette butts have a share of about $10 \%$ of the total beach litter item numbers. On the remote part of the Curonian Spit only single butts were found, indicating the lack of beach visitors. The number of particles during the regular survey for five transects varied from 137 to 245 items per transect and systematic gradients were not visible (Fig. 4). Transect 5 showed the highest amounts, but the reason behind that was 
Fig. 4 Survey of 5 transect on a the remote part of the Curonian Spit in Lithuania. Top: results of surveys together with control surveys that took place afterwards by another team. Bottom:

Composition of litter items

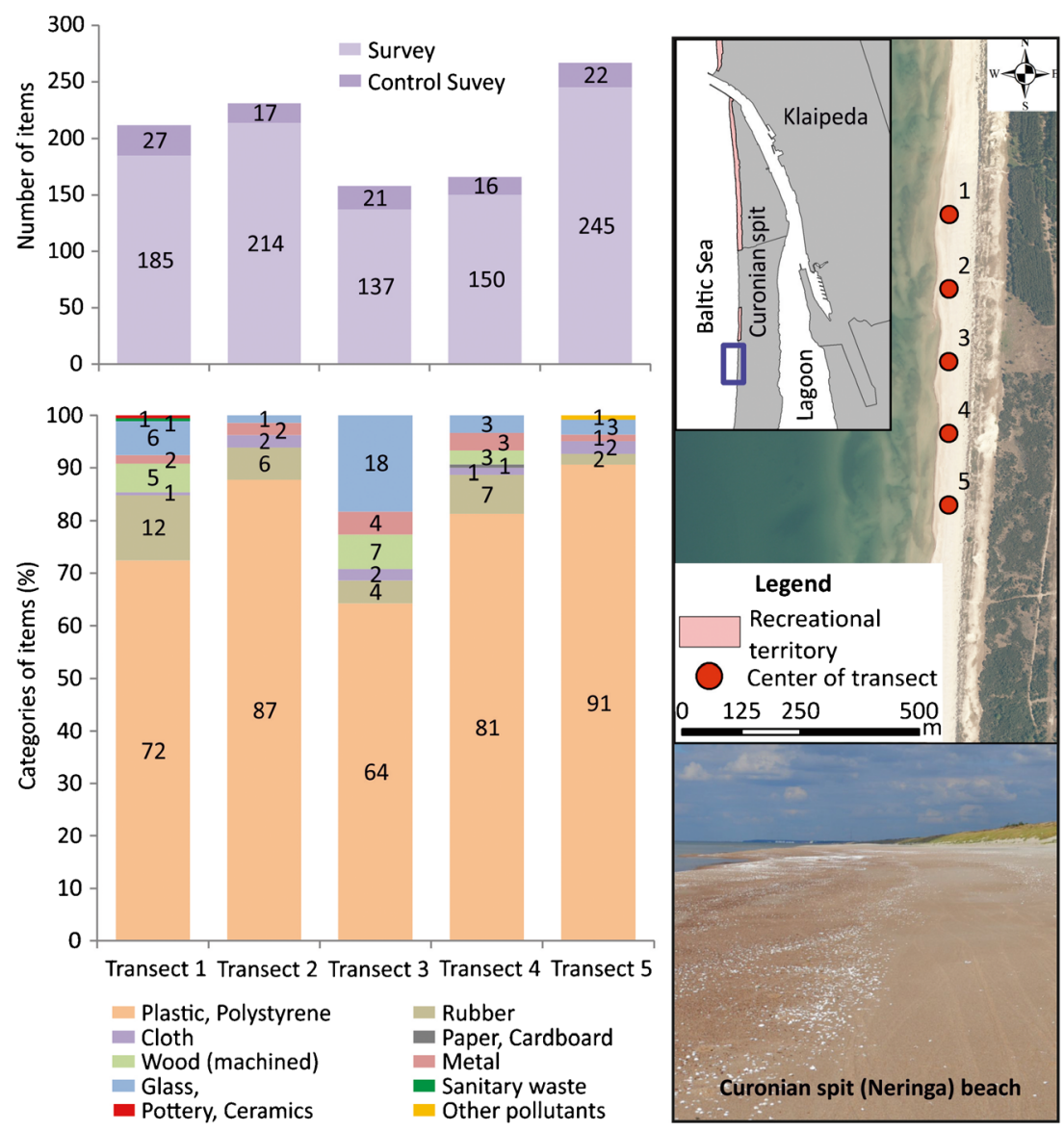

that a basket of pre-collected litter was found during the survey. However, even when neglecting transect 5 , the relative difference between lowest and highest recorded amount was $56 \%$. We can conclude that even on remote neighbouring beaches without any known gradients as well as similar structure and exposition to pollution small scale spatial variability is very high and cannot be explained.

The relative share of different item categories (Fig. 4), shows that with $64-91 \%$ plastic is dominating on all transects followed by rubber and glass. Out of the ten most common single items, eight were made of plastic. Most abundant are 'Other plastic/polystyrene items' (119 items), 'String and cord' (diameter less than $1 \mathrm{~cm}$ ) (110 items) and 'Small plastic bags', e.g., freezer bags (108 items). 'String and cord' (diameter less than $1 \mathrm{~cm}$ ) is the item, surveyors most often failed to see and was found only during the control survey. Despite a high variability between the relative share of item categories, the general pattern, the dominance of plastics, is stable.

Kägsdorf beach, west of the seaside resort Kühlungsborn, was used for the fourth experiment. Five $100 \mathrm{~m}$ transects have been defined and were monitored to settle three questions: a) Does it make sense to always carry out the survey on two neighbouring transects (replica) to get more reliable data and a better impression of small scale variability? b) Is a higher temporal density of the monitoring (monthly surveys) beneficial and is the data comparable to surveys 4 times per year? c) Does monthly data provide a better insight into seasonal pattern of beach litter accumulation, as suggested by JRC (2010)?

For this purpose, the first two transects (T1: $100 \mathrm{~m}$ and T2: $200 \mathrm{~m}$ east of a parking place) were sampled 4 times a year and another 3 transects (T3: $300 \mathrm{~m}, \mathrm{~T} 4: 400 \mathrm{~m}$ and T5: $500 \mathrm{~m}$ east of the parking place) were surveyed on a monthly basis between July 2014 and April 2015 (Fig. 5).

The results showed an evident decline in total item amounts from the first transect (T1) to the last one (T5). In Kägsdorf the first transect almost always showed higher item numbers (average of 107) than the second one (average of 66) and the latter could hardly be regarded as a replica (Fig. 5a). Transects 3 to 5 showed average item amounts of 56 (T3), 39 (T4) and 31 (T5). The more remote stations (Darß as well as Krummensteert and Wallnau on Fehmarn island) did not show a systematic difference of total amounts/composition of items found between neighbouring transects. Similar to the results from the Curonian spit, the difference between neighbouring transects in Kägsdorf showed a high variability, exceeding $100 \%$. We can conclude that replicas allow an averaging of item numbers and may produce more stable monitoring results. 
Fig. 5 a Beach surveys with replicas (neighbouring $100 \mathrm{~m}$ transects) at Kägsdorf, Darß as well as Krummsteert and Wallnau on Fehmarn (see Fig. 6) at the Baltic Sea. b Data from Kägsdorf with 4 surveys per year (transects $1 \& 2$ ) and monthly data collections (transects $3,4 \& 5$ ) a

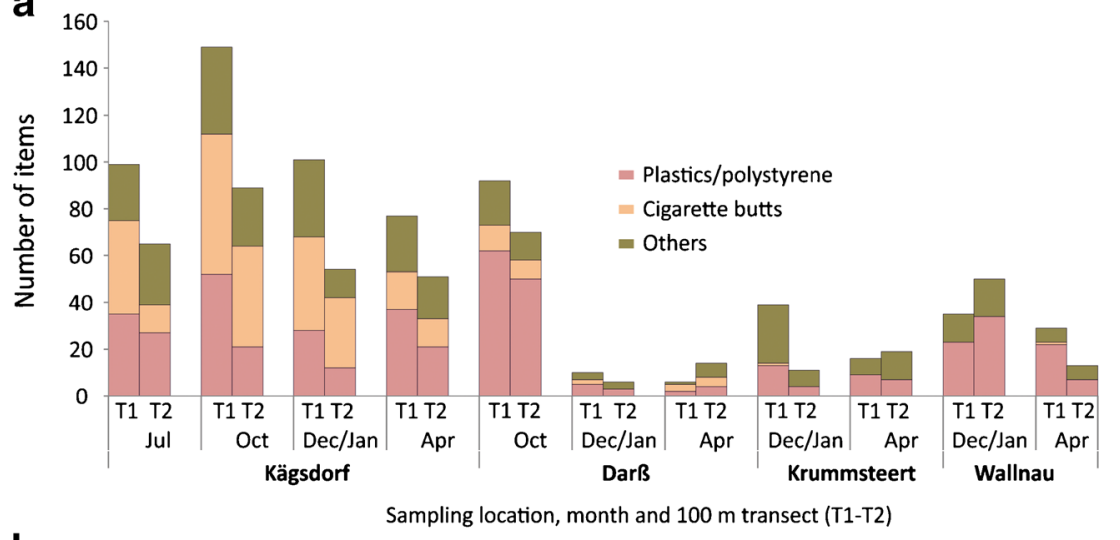

b

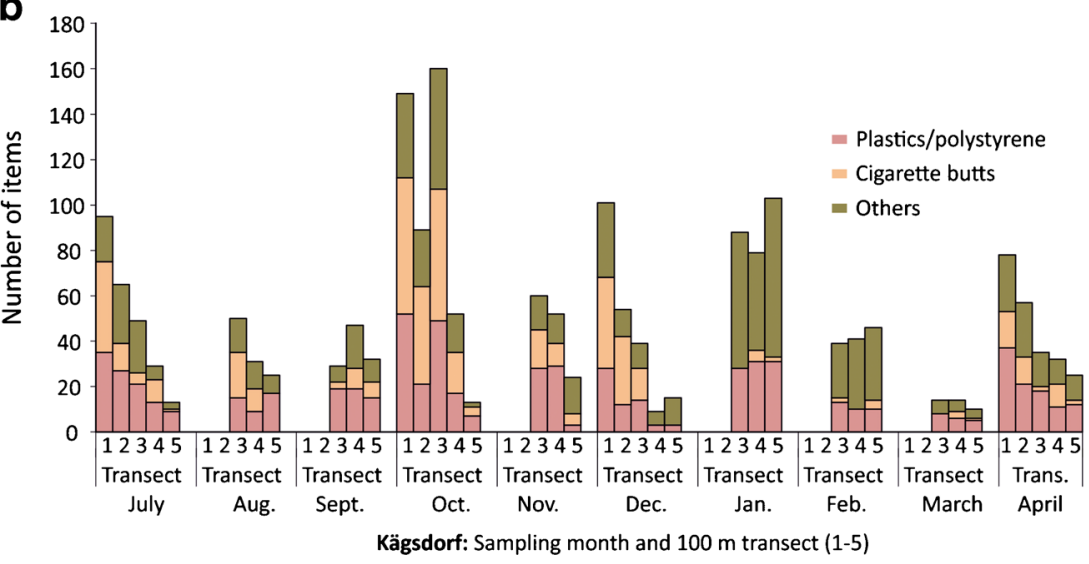

The further the distance of a transect was from the parking place and beach entrance in Kägsdorf, the lower was the number of items recorded (Fig. 5b). This indicates that beach visitors are the major source of pollution. In Kägsdorf, the absolute number as well as the relative share of cigarette butts compared to the total item amounts decreased steadily from T1 (106 cigarette butts in average, $37 \%$ of the total) towards $\mathrm{T} 5(30,8 \%)$. This indicates that the number and the relative share of cigarette butts found on a transect is suitable for indicating and quantifying pollution from beach visitors.

Most German Baltic coastlines face a coastal retreat already for centuries. Near Kägsdorf, the retreat takes place at a speed of about $35 \mathrm{~m}$ per century. Several buildings were destroyed by erosion and leftovers, like bricks and other treated material, are accumulated and found at the beach. Per OSPAR definition, these items have to be taken into account during surveys. However, natural stone often can hardly be distinguished from wave processed bricks and this reduced the accuracy of the monitoring results especially in Kägsdorf, at least for one litter category.

The time series of marine litter accumulation at Kägsdorf beach (Fig. 5b) did not show a seasonal pattern. Different to our expectations, the litter accumulation during summer season with many beach visitors was not higher compared to other seasons. The estimated sources of litter in Kägsdorf did not differ from other beaches (Fig. 9), therefore a prominent role of sea-based litter could be excluded. This means that the higher monthly sampling frequency does not provide additional information. The absolute numbers of items found on all 5 transects over the entire sampling year, we end up with T1: 423; T2: 265; T3: 676; T4: 463; T5: 367 . The results indicated that the more often monitoring takes place, the higher the total number of items per year will be. Monthly sampling data is not comparable to and could not easily be re-calculated into 3 -monthy sampling results. Taking into account the existing pollution gradient in Kägsdorf, we can estimate likely annual numbers of items for all transects based on a 3 -monthly sampling. The annual item numbers resulting from a monthly sampling exceeded these numbers by $300 \%$ and more. Therefore, if we carry out the monitoring 3 times more often, we get 3 times higher total annual item numbers. The sampling history, if a survey with cleaning took place one or three months before or even a year ago, did not affect the monitoring result in Kägsdorf. This is well in agreement with our statistical results covering all sampling beaches. Obviously, a steady accumulation of litter at the beach 
over a period of months does not take place. The exposition of the beach to dominating westerly winds and the relatively low specific weight of the majority of beach litter items compared to sand seem to favour the translocation of items along the beach. Permanently moving litter seems to wipe out effects of beach samplings or cleanings in time-scales of days to weeks. We can conclude that a monthly sampling does not provide significantly better insights, but triple the monitoring effort with respect to time and labour. The JRC (2010) recommendation to consider monthly surveys cannot be confirmed by our results, on the opposite. Our observations are supported by Smith and Markic (2013), who analysed the effect temporal scales of sampling on marine litter results on beaches. In their study, a daily sampling delivered $50 \%$ higher total item quantities compared to a 3 day sampling interval and an order of magnitude higher values compared to a monthly sampling interval.

Figure 6 shows the effect of the high variability between the 4 sampling seasons on the average number per survey and on potential temporal tends. The average annual item number over the 4 years was 52 (Vilm), 160 (Binz) and 591 (Göhren). On Vilm, by accident, the average amounts per survey were nearly similar from 2012 to 2015, despite strong variabilities within the seasons. In Göhren and Binz the effects of high item numbers obtained during one single survey on the annual average becomes visible. Trends could not recognizable during the 4 years at any beach. The results indicate that even time series over ten years, will hardly allow the detection of trends in item numbers.

A high variability in litter amounts between surveys on a given beach and between neighbouring beaches is known from the North Sea, as well (Schulz et al. 2013). Schulz et al. (2015b) analysed the 25 years beach macro litter data series for 8 German North Sea beaches and pointed out that it was difficult to identify long-term trends. The temporal variability on southern Baltic beaches seemed to be even stronger compared to the more remote North Sea beaches. This high variability may be a limiting factor for the detection of trends even if a monitoring would be maintained over decades.

\section{Amounts and composition of macro-litter at the coast}

Altogether 31 German and 4 Lithuanian Baltic beaches were subject to a regular monitoring mainly carried out by trained volunteers 4 times a year. Along the Lithuanian coast the number of items per survey varied between 138 (Palanga) and 340 (Klaipeda) with a mean value of 222 items (Table 1). Along the German Baltic coast the item numbers varied in a much wider range between 7 (Zingst) and 404 (Mukran) with a median value of 47 (the mean value is dominated by extreme abundancies in Mukran). We could nott entirely exclude that some of the extremely low numbers are affected by beach cleaning. However, the observed values in Lithuania exceed the German Baltic values by more than 3 times. At the North Sea coast, 211 items per survey were observed on remote locations on Sylt island and 103 on Juist island. Compared to German Baltic beaches this is $1.5-3$ times higher. While the Lithuanian coastline is relatively homogeneous with respect to structure and exposition, the German Baltic coastline is characterised by a complex morphometry, different expositions and many embayments. As consequence, the numbers of items between beaches within a region, like the island of Rügen, showed a strong spatial variability (Fig. 7). Based on the existing monitoring a reliable estimation of the total annual

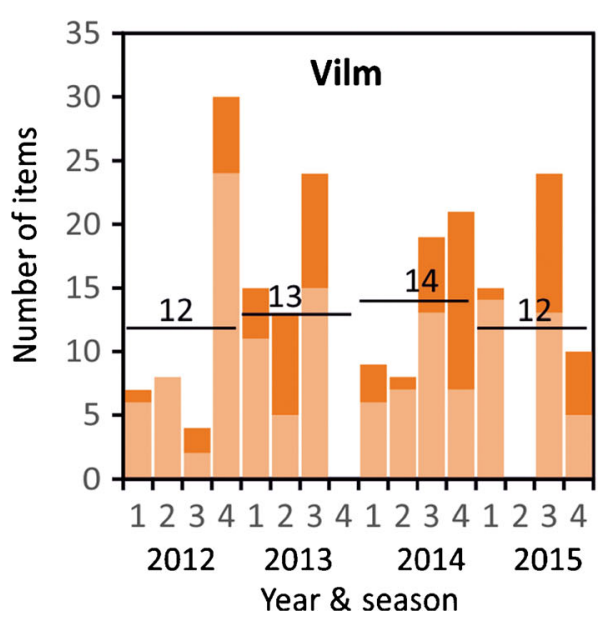

Fig. 6 Total number of items and number of plastic items at three beaches with contrasting pollution states and the longest beach survey time-series at the German Baltic coast (2012-2015). The bars indicate the
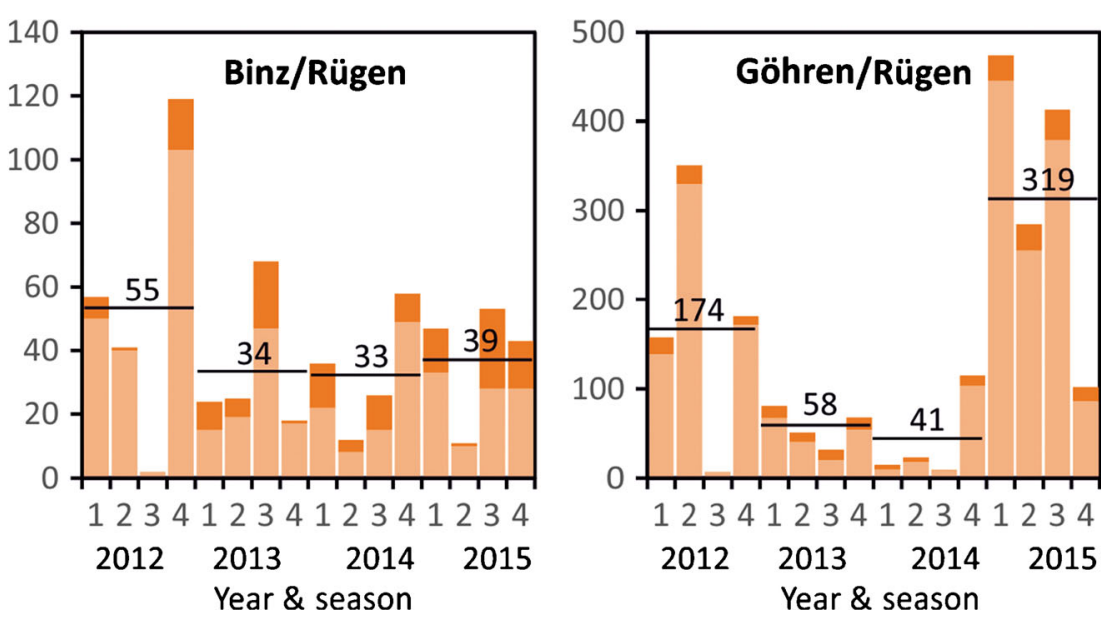

item numbers per survey (1: winter, 2: spring, 3: summer, 4: autumn) and the black lines with numbers represent the average per survey over a year 
Table 1 Results of descriptive statistical analyses: Means and standard deviations of abundances of total beach litter. $\mathrm{N}$ gives the numbers of beach surveys

\begin{tabular}{|c|c|c|c|}
\hline Beach & Mean $[-]$ & Standard deviation $[-]$ & $\mathrm{N}$ \\
\hline Binz & 35.9 & 31.4 & 14 \\
\hline Boiensdorfer Weder & 25.6 & 10.5 & 7 \\
\hline Bug & 47.3 & 37.9 & 7 \\
\hline Darss Weststrand & 99.7 & 92.9 & 7 \\
\hline Fehmarn Grüner Brink & 131.9 & 70.9 & 14 \\
\hline Fehmarn Krummsteert & 36.7 & 29.5 & 13 \\
\hline Fehmarn Wallnau & 84.1 & 31.9 & 14 \\
\hline Glowe & 145.6 & 95.9 & 9 \\
\hline Göhren & 79.4 & 96.5 & 14 \\
\hline Greifswalder Oie & 47.4 & 16.4 & 7 \\
\hline Hiddensee Gellen & 14.2 & 5.9 & 6 \\
\hline Hiddensee Neubessin & 14.0 & 12.1 & 7 \\
\hline Hohe Düne & 61.6 & 18.9 & 5 \\
\hline Kägsdorf & 86.9 & 54.8 & 9 \\
\hline Karkle & 238.6 & 68.5 & 8 \\
\hline Klaipeda & 339.8 & 73.0 & 8 \\
\hline Klein Zicker & 23.1 & 27.3 & 9 \\
\hline Lubmin & 28.4 & 18.3 & 5 \\
\hline Ludwigsburg & 33.4 & 13.8 & 5 \\
\hline Mukran & 404.4 & 227.1 & 9 \\
\hline Nemirseta & 173.3 & 31.6 & 8 \\
\hline Nobbin & 107.2 & 126.8 & 9 \\
\hline Palanga & 138.0 & 70.0 & 8 \\
\hline Poel & 41.4 & 27.1 & 7 \\
\hline Rosenhagen & 51.6 & 14.2 & 7 \\
\hline Sellin & 106.2 & 103.9 & 9 \\
\hline Steinbeck & 55.3 & 39.3 & 7 \\
\hline Stubbenkammer & 15.4 & 12.1 & 7 \\
\hline Tarnewitzer Huk & 18.7 & 4.5 & 7 \\
\hline Usedom & 122.8 & 15.0 & 5 \\
\hline Varnkevitz & 70.2 & 48.1 & 12 \\
\hline Vilm & 14.5 & 8.5 & 14 \\
\hline Warnemünde & 73.8 & 35.0 & 5 \\
\hline Zingst Kirchweg & 6.9 & 4.7 & 7 \\
\hline Zingst Wasserweg & 13.2 & 7.4 & 6 \\
\hline
\end{tabular}

beach litter numbers for the entire German Baltic Coast is not possible (Tables 2 and 3).

The beach litter composition (Fig. 7) shows that plastics is the most important item category. In some places, paper items play an important role. Often, strong differences in the composition were a result of low item numbers. In Fig. 7, cigarette butts were counted as paper according to OSPAR. For example, during surveys on the island of Poel, out of 40 total items, 20 belonged to the paper category and 18 were cigarette butts. With 57 the highest average accumulation of cigarette butts was observed in Mukran, a large bay on Rügen island. At the Lithuanian and German Baltic coasts, cigarette butts have a share of about $10 \%$, but because of high item numbers in Lithuania, the absolute numbers of cigarette butts are above $20 \%$. Beside plastic items, cigarette butts are a major problem in the Baltic.

A cluster analyses with top items as input data was carried out to analyse possible similarities between single beaches and/or different regions. Further, we wanted to address the question, which beaches can be regarded as representative for a larger number of others or a region and should be considered in a permanent monitoring programme.

The analysis of variance did not give significant differences between the first and second survey carried out at each beach ( $p=0.594, n=58)$. Mean values and standard deviations of total abundances of the first surveys were only slightly higher than those of the second surveys and amounted to $107.4 \pm 112.5$ and $102.2 \pm 151.3$ for the first and second surveys, respectively. Therefore, results of the first surveys could be included in the input data of subsequent cluster analyses. Cleaning due to picking up items during the first survey had no significant effects on the second survey, three month later.

Altogether 5 cluster analysis using the methods single linkage, complete linkage and Ward have been carried using different distance measures of proximity (Euclidean distance, 1Pearson correlation coefficient). The dendrogram resulting from single linkage cluster analysis identified Mukran as outlying beach, which was removed from subsequent cluster analyses.

According to results of cluster analyses applying the Ward method (Fig. 8), beaches were grouped due to similar degrees of pollution rather than to their topographical positions. However amongst others, the four Lithuanian beaches lied in the same cluster, indicating similar high degrees of pollution, while beaches in environmental protection areas or remote from touristic sites, such as Stubbenkammer and the two beaches on the island of Hiddensee, were grouped into another cluster. This gives a hint on touristic activities as major source of beach litter at least at the German coast of the Baltic Sea.

As in all other cluster analysis, the four Lithuanian beaches were grouped into the same cluster when applying complete linkage. Few clusters combined beaches, which lied in close topographical vicinity to each other, such as two beaches on the island of Fehmarn. However apart from this, clustering was scarcely plausible when considering expositions to touristic activities or sea-based sources. Cluster analyses based on only seven items as input data and applying different methods, indicated certain relationships, but alone were not able to provide reliable results. 

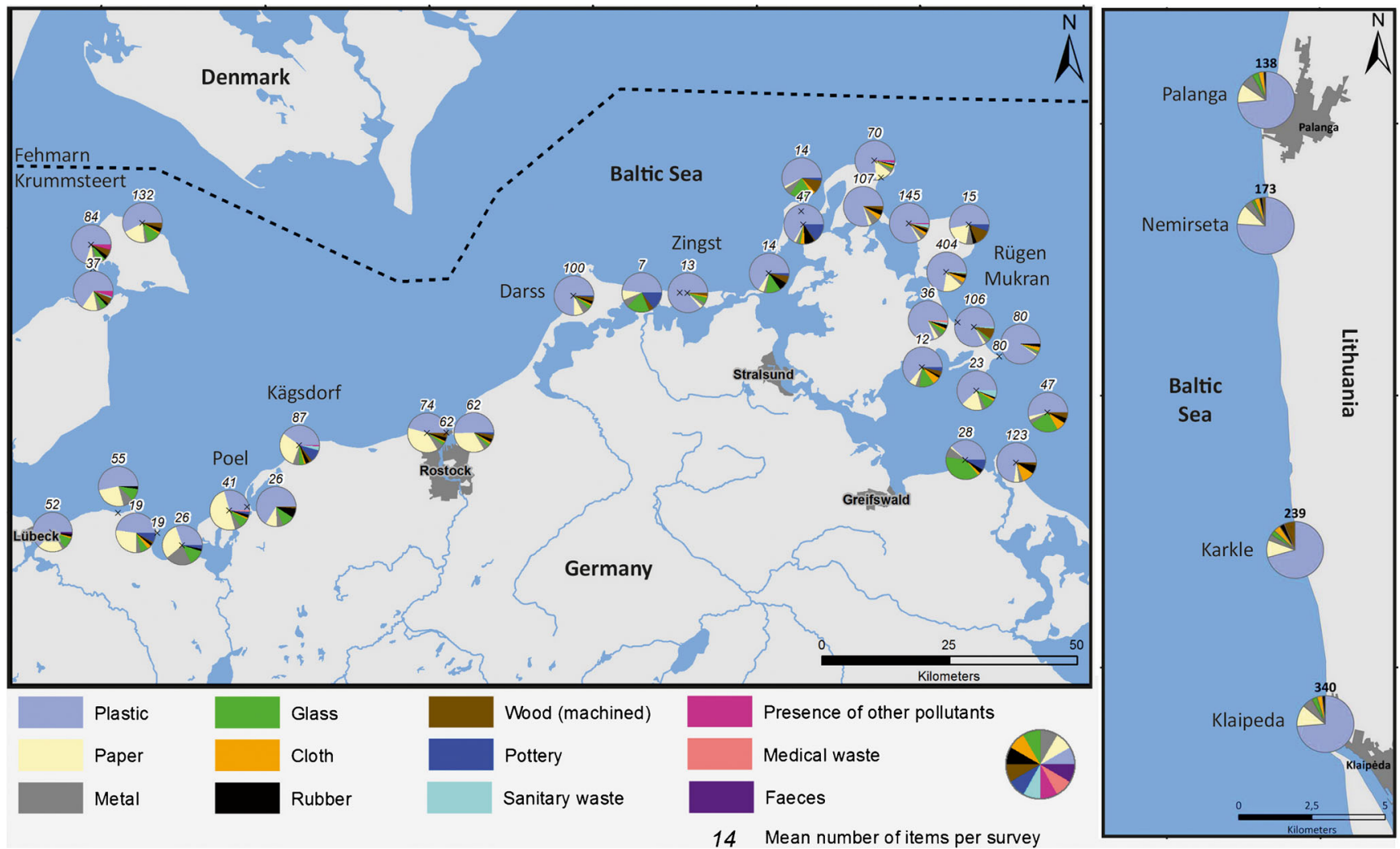

Fig. 7 Location, average number of items and composition of macro-litter at German and Lithuanian Baltic Sea beaches per survey (4 surveys/year). Cigarette butts are counted as paper. (Graphics: M. Schott)

Until present, cluster analyses have seldom been performed to group beaches according to pollution with marine litter (Schulz et al. 2013; Williams et al. 2003). The latter authors identified beaches with significantly different beach litter profiles, as it was successfully done in this study. Based on cluster analyses with the top 13 items of beach litter, tourism could be

Table 2 Results of descriptive statistical analyses: Mean, minimum and maximum values of percentages of general categories of beach litter $(n=35$ beaches $)$

\begin{tabular}{lrrr}
\hline Material & Mean & Minimum & Maximum \\
\hline Plastic • Polystyrene & 63.8 & 29.3 & 88.8 \\
Rubber & 2.8 & 0.0 & 8.2 \\
Cloth & 2.3 & 0.0 & 9.9 \\
Paper • Cardboard & 12.5 & 1.1 & 49.0 \\
Wood (machined) & 3.1 & 0.0 & 13.0 \\
Metal & 4.4 & 2.2 & 8.5 \\
Glass & 7.2 & 0.4 & 38.0 \\
Pottery • Ceramics & 2.3 & 0.0 & 14.8 \\
Sanitary waste & 0.7 & 0.0 & 5.3 \\
Medical waste & 0.2 & 0.0 & 1.6 \\
Faeces & 0.1 & 0.0 & 1.4 \\
Presence of other pollutants & 0.6 & 0.0 & 5.4 \\
\hline
\end{tabular}

identified as dominant source of beach litter at the coast of the southern Baltic Sea.

\section{Analysis of macro-litter sources}

To complement the Cluster analysis and to get a more detailed insight into sources of pollution, the Matrix Scoring Technique for the analysis of beach litter sources from Tudor and Williams (2004) was applied. Considered were all German Baltic Sea beaches, contrasting beaches in Lithuania and, for comparison, 4 selected beaches at the German North Sea coast on the islands of Sylt and Juist (Fig. 9).

The Lithuanian beaches are exposed towards west, the open Baltic Sea, and westerly winds are by far dominating. The expectation was that they would show a similar source distribution like beaches at the North Sea, with a relative high share of litter from shipping and fisheries. This was not the case. Tourism was by far the dominating source of litter (61\%). The German Baltic beached showed a pronounced variability in the source distribution but altogether a higher similarity to the Lithuanian beaches compared to the German North Sea beaches. At the German Baltic beaches tourism is the most important litter source $50 \%$ of the total average) followed by sewage (25\%), shipping (10\%), offshore installations $(8 \%)$ and fisheries $(7 \%)$. Open sea activities 
Table 3 The 13 most important items of beach litter of all beaches considered for statistical analyses ( $n=35$ beaches)

\begin{tabular}{lll}
\hline OSPAR-ID & OSPAR item & $\begin{array}{l}\text { Number of ranks among the } \\
\text { top ten items per beach }\end{array}$ \\
\hline $46^{*}$ & Plastic/polystyrene pieces $2.5 \mathrm{~cm}><50 \mathrm{~cm}$ & 34 \\
15 & Caps/lids & 28 \\
19 & Crisp/sweet packets and lolly sticks & 25 \\
64 & Cigarette butts & 22 \\
$93 *$ & Other glass items & 22 \\
$117^{*}$ & Plastic/polystyrene pieces $0-2.5 \mathrm{~cm}$ & 21 \\
3 & Small plastic bags, e.g., freezer bags & 19 \\
32 & String and cord (diameter less than $1 \mathrm{~cm})$ & 18 \\
4 & Drinks (bottles, containers and drums) & 17 \\
$48^{*}$ & Other plastic/polystyrene items & 15 \\
$45^{*}$ & Foam sponge & 13 \\
$74 *$ & Other wood $<50$ cm & 13 \\
40 & Industrial packaging, plastic sheeting & 12 \\
\hline
\end{tabular}

*Non-identifiable fragment items, which were removed from input data in additional cluster analyses seemed not to play such an important role as litter sources in the German Baltic Sea (25\%) like in the North Sea (51\%). These results confirmed the impression received from the cluster analysis.

The methodology has several weaknesses and uncertainties, but is one possibility to get a better quantitative insight into sources of pollution. This is required to properly address sources and to test the effectiveness of pollution control measures. Likelihood scores that need to be defined for the Matrix Scoring Technique, must be set at a regional level, because the source of a given item can differ depending on the region (Tudor and Williams 2004). The likelihood scores applied to the Baltic Sea were also used for the North Sea data set, therefore the relative importance of the different sources calculated for the North Sea may not be correct. Further, the methodology bears several weaknesses. The value for tourism and recreation, for example, included data from numerous items, which can also originate from shipping-related activities. Usually, it is not possible to differentiate between litter items originating from offshore installations and shipping related activities and, with some items, those originating from commercial shipping-related and fishing-related activities. However, as many sources are the same for both the Baltic Sea and the North Sea, e.g. for some fisheries-related litter items e.g. nets, the matrix scoring technique did show some real differences between the two regions.

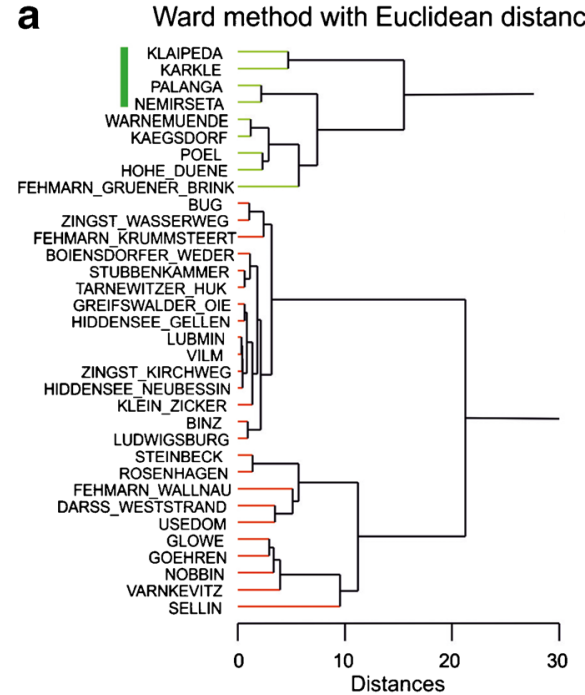

Fig. 8 Dendrogram resulting from a cluster analysis a applying the Ward method together with Euclidean distance as well as b complete linkage together with 1-Pearson correlation coefficient as measure of proximity.

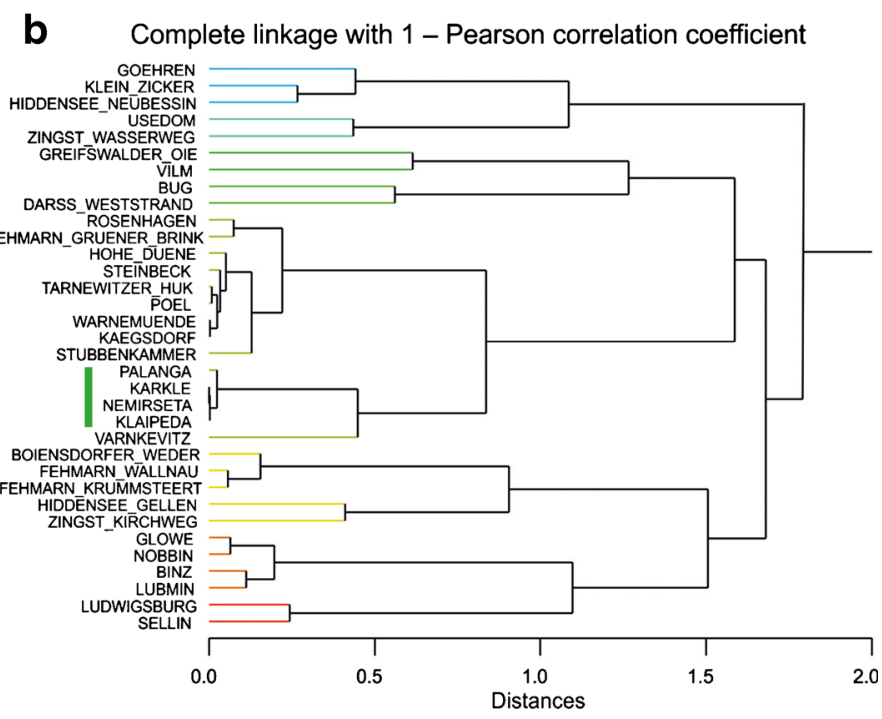

Mean abundance values of seven important beach litter items were used as input data. Beaches of the same cluster are marked with the same colour. The Lithuanian beaches are indicated by a green bar 


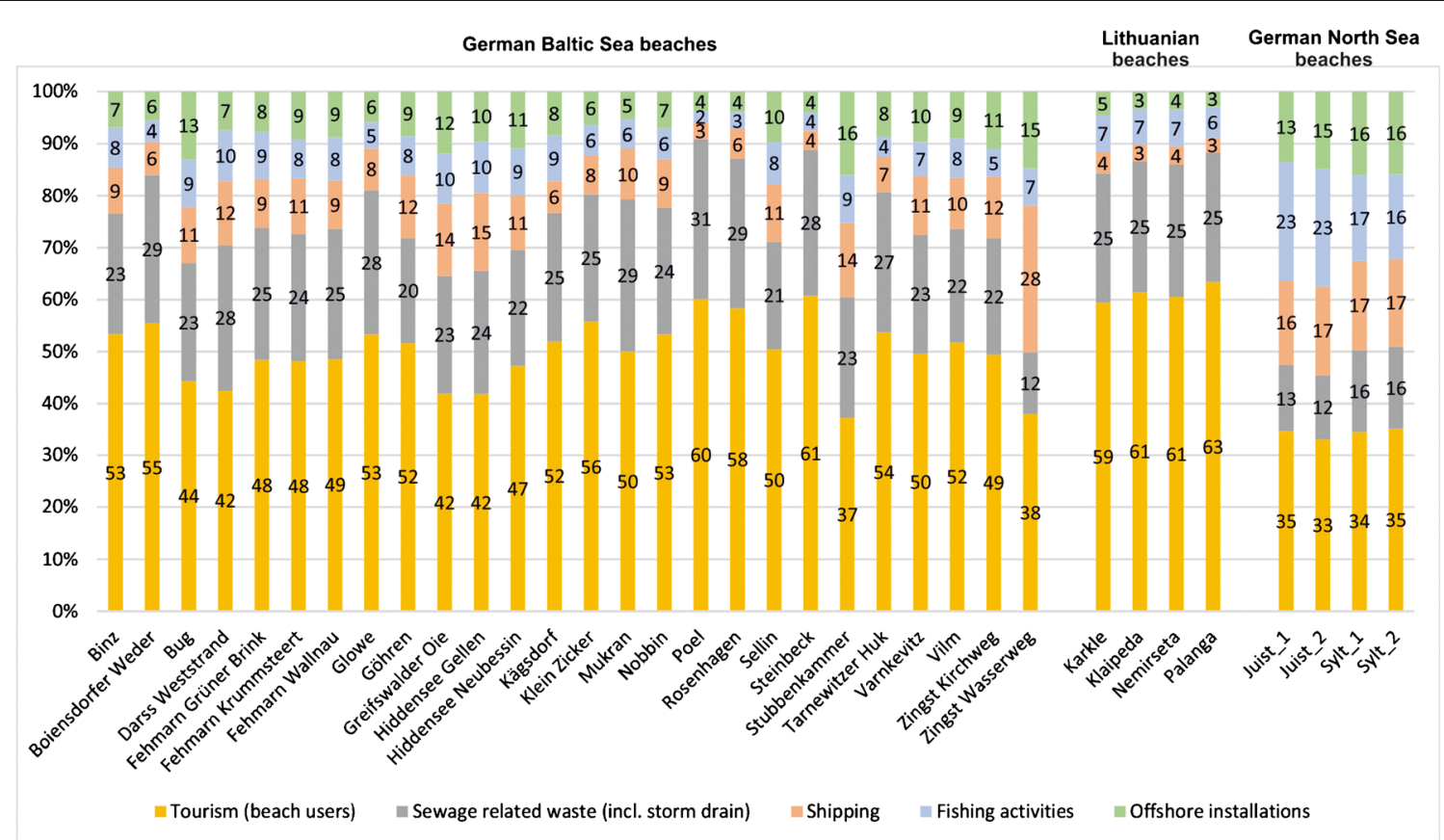

Fig. 9 Sources of observed beach macro-litter, estimated with the Baltic Sea adapted Matrix Scoring Technique (Tudor and Williams 2004) for 26 German Baltic Sea beaches, 4 beaches in Lithuania and, for comparison,

\section{Model simulations on emission, transport and fate of macro-litter}

To get a first insight and better understanding why certain marine litter sources seem to be of outstanding importance in the Baltic, like tourism, and others have a minor relevance, like shipping, model simulations with the 3D flow and transport model GETM have been carried out. The simulations should provide a spatio-temporal impression on how floating marine litter, origination from shipping and major seaside tourism resorts are transported in the sea and on where this litter is finally accumulated. This approach should help to allocate major emission sources and accumulation hot-spots along the coast as well as to explain the large-scale differences in spatial beach litter numbers and composition pattern (Fig. 7).

Figure 10 shows model simulations results assuming hypothetical marine litter from shipping for western Baltic Sea. Generally, the comparison of the seven years covered in the simulation revealed distinct similarities in the litter distribution, with just 2009 differing significantly from the other years. For this reason, only the graphs for 2005, 2007 and 2009 were shown. The results can be summarized as follows: a) on an annual average, the southern coasts of Denmark showed the highest pollution from shipping (Lolland, spit of Gedser Faxe Bugt) throughout all years; b) at the German coast a high degree
4 North Sea beaches. Tourism as a source includes all recreational activities on the beach and in the surf zone

of litter accumulation (hot-spots) was suggested for Rügen islands northern shore (Varnkevitz/Putgarten), Darß-Zingst peninsula, Graal-Müritz/Dierhagen and Fehmarn island; c) in contrast, the south coasts of Sweden and Bornholm usually did not show much litter accumulation; d) single years, like 2009, can provide an opposite picture with high accumulations on the Swedish coast. However, the model simulation results for beaches were hypothetical and required a validation by beach monitoring data.

In general, seasonal variations of litter accumulation were not pronounced and pollution hot-spots showed high accumulations in all seasons. This confirmed the results shown in Fig. 5. In 2009, when unusual low annual mean litter amounts were calculated for the southern Baltic Sea shore and high concentrations in Sweden, this was different. Most of the annual accumulation in Sweden took place during autumn and winter (Fig. 10). A comparison between the long-term seasonal climatologic average wind directions and the situation for 2009 matched very well, especially for autumn. A difference in prevailing wind directions cannot explain the high accumulation in Sweden. The model simulations helped understand where beaches with relatively low and high abundances of litter item from shipping were located, without being able to fully explain the observed pattern (Fig. 7). So far, the model only considers litter floating with currents and 
Fig. 10 Simulations with the 3Dflow and transport model GETM covering the western Baltic Sea. The scenario assumes hypothetical emissions of floating litter particles by ships. Location and amount of emissions reflect shipping intensity. Top figures: Relative annual mean values of litter accumulated along the coast for the years 2005, 2007 and 2009. Center: Hotspot regions with high average annual litter accumulation for the years 2003, 2005, 2007, 2009. Bottom:

Seasonal litter accumulation for the year 2009. Background Maps by Natural Earth 2013, BKG and EuroGeographics
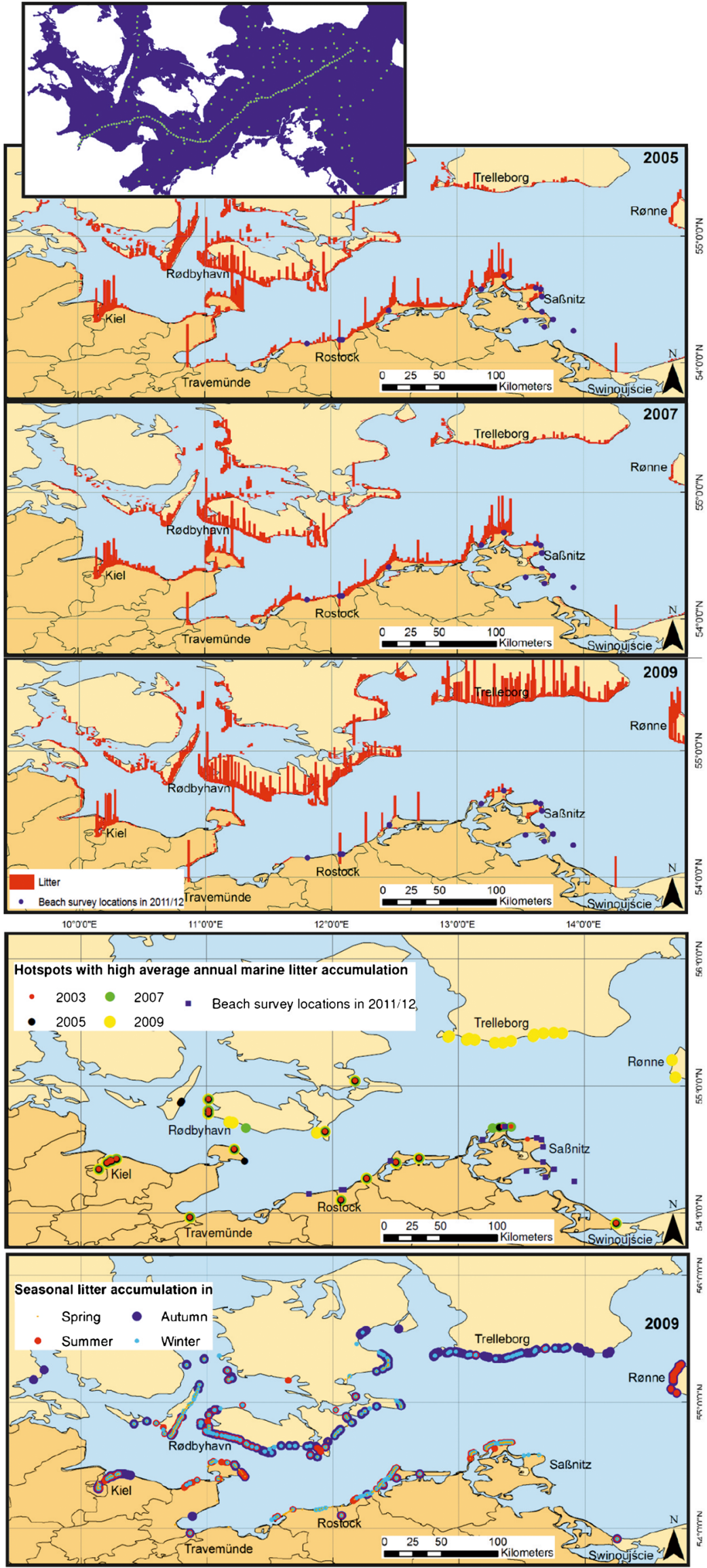
much of it ended up in Denmark and few hot-spots along the German Baltic coast. Most of the coast was not affected by shipborne litter pollution. However, the simulations took into account only a fraction of all litter. Heavy litter material would sink to the bottom and underlie very different transport processes. Litter with very low densities is subject to wind-driven transport and will very likely be transported with the prevailing winds towards north-east and not end-up along the German coastline. Altogether, we can assume that litter emitted on sea has not a high likelihood to end-up at German Baltic beaches. This explains the relative low importance of shipping as a litter source, especially at the Germany coast.

The model simulations assuming a release of marine litter from the coastal resorts Warnemünde and Kühlungsborn (Fig. 11) tooke into account different wind scenarios. The results suggested that for Warnemünde, most of the emitted litter ( $\geq 50 \%$ ) would be accumulated at the coast close by. In Kühlungsborn, the situation was different. Here, conditions were found under which hardly any of the litter remained at its entry point. This was the case particularly for strong and steady west winds as well as for south winds. However, $\geq 50 \%$ of the litter was trapped on the about $70 \mathrm{~km}$ long coastal stretch eastwards and north-eastwards. This result is valid for an emission outside the wave surge zone. Emissions from the beach into the wave surge zone would, very likely, accumulate locally at the coast. However, very likely, most litter is released from the beach and has to pass the wave surge zone, which usually covers a strip of $50 \mathrm{~m}$ and more. Waves usually cause a fast accumulation at the shore. This can be seen during fireworks and harbours celebrations in Rostock-Warnemünde, when remnants accumulate the days afters in the tidal zone of beaches in the harbour vicinity. Wave surge was not implemented in the model system and the accumulation process may be faster and even closer to the emission areas than suggested by the model.

The western Baltic Sea has a ragged coastline and no point in the sea is further than $30 \mathrm{~km}$ from a coast. As consequence, floating litter emitted into the western Baltic Sea does not remain on sea for long, but will be accumulated on coasts usually within days. During summer seasons, most southern Baltic beaches are intensively used by bathing-tourists and visitors. Beach cleanings, often take place on a daily basis at that time. It means that litter is frequently removed from the Baltic coastlines, a translocation of larger litter amounts or areas with long-term accumulations are the exception. This specific situation is one explanation for the comparatively low beach litter concentrations compared to other seas.

Several Lagrangian drift models have been successfully applied to simulate the transport of marine litter (e.g. Potemra 2012; Neumann et al. 2014). Potentially, model simulations could be compared to beach accumulation data and backward simulations could allow the identification of emission source locations and could complement other source analysis methods. However, Neumann et al. (2014) showed that this is problematic in practice, because it requires temporal high resolved, daily accumulation data. Because of a lack of suitable survey data, we restricted our model applications to few hypothetical simulations to obtain a better insight into transport processes in the western Baltic Sea.
Fig. 11 Model simulation with GETM. The scenarios assumes litter emissions at the seaside resorts Warnemünde and Kühliungsborn. The figures show the litter transport for different periods with different wind direction and speeds indicated by arrows. The colour scale provides information on the particle's concentration with $100 \%$ corresponding to the initial state
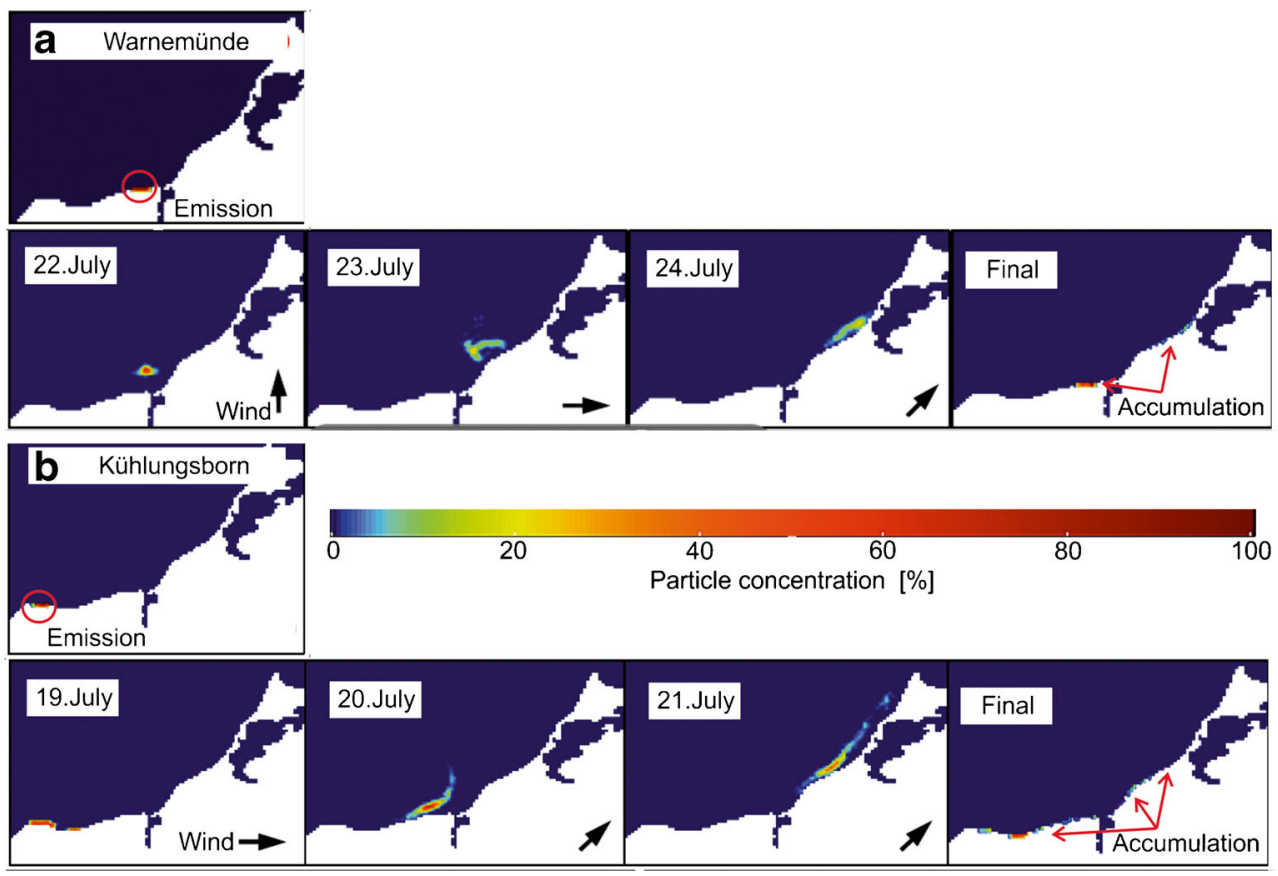


\section{Beach macro-litter effects on birds}

So far, indicator species to monitor the trend of marine litter affecting animals in the Baltic Sea, comparable e.g. to the Northern Fulmar in the North Sea (Van Franeker et al. 2011), do not exist. It has been shown that marine debris can be an essential component of nesting material of different seabird species like Kittiwake (Rissa tridactyla) in northwest Denmark, European shag (Phalacrocorax aristotelis) in west France, Northern gannets (Morus bassanus) in Newfoundland, Wales and on the island of Helgoland (Montevecchi 1991; Hartwig et al. 2007; Cadiou et al. 2011; Votier et al. 2011). As there are related species in the Baltic Sea, an investigation of nesting material was carried out. We considered the cormorant species Phalacrocorax carbo sinensis as most promising and relevant for nesting analysis.

40 nests were analysed and 23 nests contained litter. Altogether 65 litter items with a total weight of $447 \mathrm{~g}$ were found (Fig. 12). Older nests contained higher numbers of litter items. The litter mainly consisted of packaging items $(57 \%)$ and other plastic parts (31\%). Ropes (7\%) and fishing nets or pieces of those $(5 \%)$ played a minor role. The remote location of the island suggests that the birds picked up the litter either on sea or because of the very short residence time of litter in these coastal waters, more likely at the coast.

During this survey no indications were found that cormorants died due to entanglement or other direct impacts of marine litter. Additionally, the interview with the responsible ranger regularly engaged in bird observation on the island confirmed, that marine litter had not caused obvious direct cormorant mortality on the island, so far. A systematic analysis of complementary, largely unpublished regional data from other studies can be summarised as follows:

Stomachs of 83 cormorant birds (Phalacrocorax carbo sinensis) from the Greifswlader Bodden area were analysed for feeding studies between November 2002 and July 2003 (Ubl, unpublished). No evidence of plastic was found. Evert (pers. com.) investigated 130 long-tailed duck individuals and 274 individuals of common scoters from the Bay of Pomerania (Ahlbeck, Bansin, Ückeritz, Koserow, gillnet bycatch 2001-2004). No indication of larger plastic particles in their stomachs was found. Small micro-litter particles were not included in this study. Barthelmes (pers. com.) analysed 54 long-tailed ducks from the Greifswalder Bodden. Only one duck contained a small piece of fishing net. Other plastic pieces were not found. Sonntag (2009) analysed four Slavonian grebes und 23 red-necked grebe resulting from
Fig. 12 Ground breeding Great cormorant (Phalacrocorax carbo sinensis) colony located on the island Heuwiese $\left(0.14 \mathrm{~km}^{2}\right.$, $54^{\circ} 26^{\prime} \mathrm{N}, 13^{\circ} 7^{\prime} \mathrm{O}$, near Rügen island). Examined nests included plastic packaging, bags and its ends, wrapper and foils, angling line, cords and wire
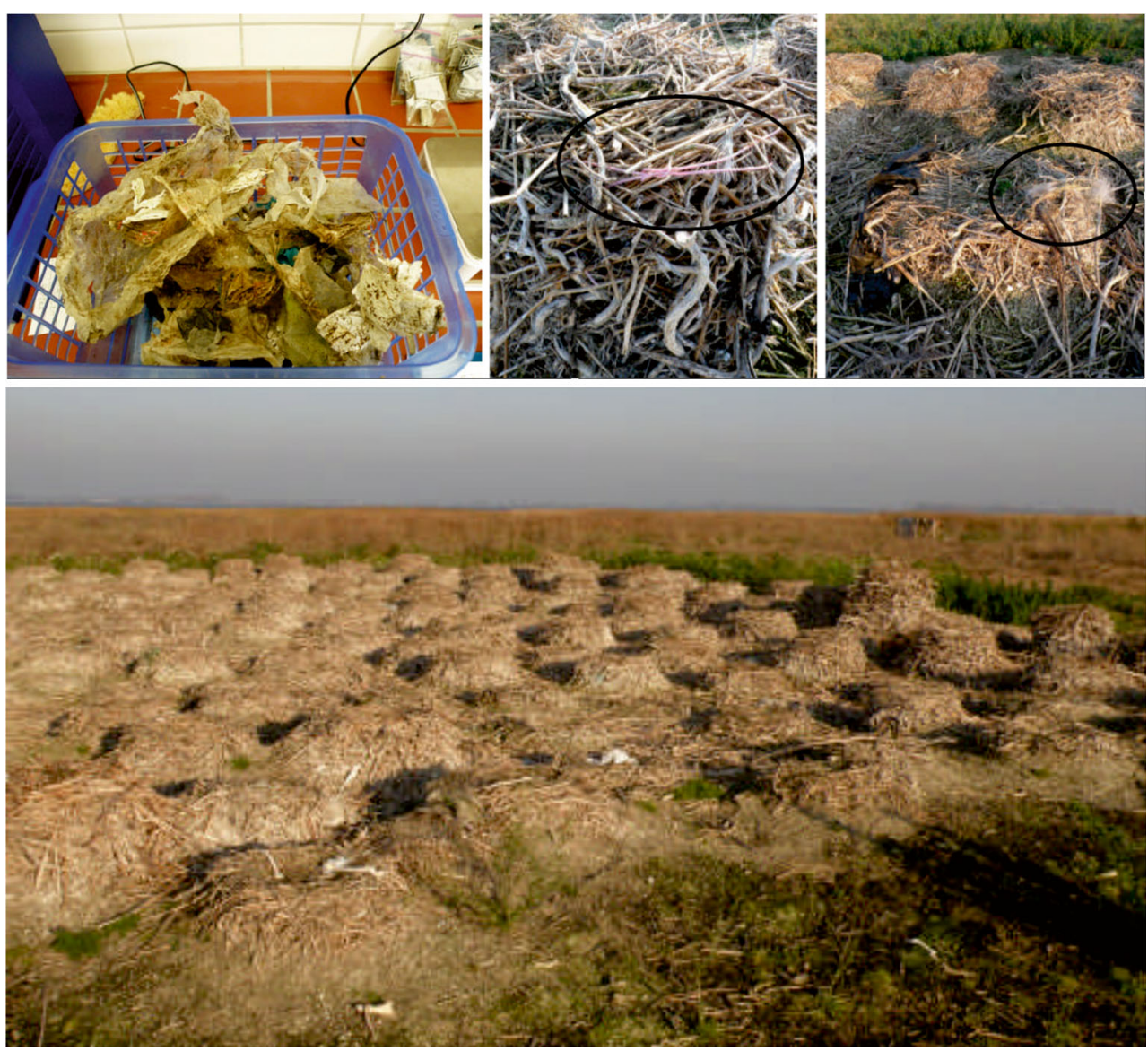
gillnet bycatch. One individual took up a little blue nylon thread (Sonntag, pers. com.). Other plastic pieces did not occur. The stomachs of 19 greater scaups, 18 common pochards and eleven tufted ducks found in gillnets around Rügen were analysed by de Jong (unpublished). No visible plastic was found in any of these ducks. During our macro monitoring surveys dead animals were not observed or reported from German Baltic beaches. It is very likely that dead animals are removed by predators, like foxes, and that our picture is incomplete.

\section{Macro-litter monitoring - lessons learnt and perspectives for the Baltic}

Beach macro-litter monitoring is a well established methodology, has been applied in the North Sea/Atlantic region (OSPAR convention area) and it is supposed to become a European-wide methodology within the MSFD. Therefore, its suitability for the Baltic region needs to be evaluated.

The Baltic shows properties that differ significantly from the North Sea/Atlantic region. It is an inland sea with very limited exchange to other sea regions. It has a ragged very long coastline compared to the sea surface area. In the northern, Scandinavian, region an isostatic uplift of land is ongoing. As consequence, rocky coasts dominate and beaches, that fulfil the OSPAR criteria for a suitable monitoring beach, are not that common as in the southern Baltic. Along the southern Baltic coast, many beaches exist that are potentially suitable for a monitoring. The vast majority is used for recreational purposes and regular beach cleanings are common during summer season. Major pollution sources for beach litter are beach visitors and urban areas. Other sources play only a minor role and even if litter enters the sea, it will end-up at the coast within days and weeks. In general, local emissions and a small-scale litter transport along the coast seems to dominate in the Baltic. Beach cleanings, the limited emission of litter on sea and a lack of long distance transport from oceans are responsible for the relatively low numbers of beach litter compared to the North Sea or the Atlantic Ocean.

Beaches without any human disturbances are rare. Especially at the German Baltic coast framework conditions like exposition to wind, currents or pollution sources vary on a small spatial scale and even remote beaches often show strong spatial gradients in beach litter pollution. Very likely, the local wind-driven translocation of litter along the coast has to be taken into account and influences the results at German Baltic coasts, where westerly to south-westerly winds dominate and favour a coast parallel transport of litter. This may increase the temporal variability of litter amounts. This is different in Lithuania with its west exposed beaches, were litter is trapped at the beach back. The strong spatio-temporal variability of the beach litter amounts may not allow the detection of temporal trends, based on a monitoring even over decades and within reporting periods of the MSFD. Only very long time-series can deliver information if changes in the state of pollution took place and if implemented measures were successful.

However, a macro-litter beach monitoring is being established all over Europe, and the question is how this should look like at the German Baltic coast? JCR (2013) recommends choosing beaches for survey in a way that they are subject to different litter exposures, namely urban coasts that reflect the contribution of land-based inputs; rural coasts that serve as background for litter pollution levels and coasts close to major rivers, to reflect the contribution of riverine input to coastal litter pollution. The cluster analysis and pollution source analysis at the German Baltic coast shows, that it is not possible to define one or several beaches that are representative (with respect to litter amounts and compositions) for a larger area or for a certain pollution source, because tourism/ beach visitors always plays the main role.

Our data and statistical analysis did not provide strong evidence where monitoring stations should be located. Practical and cost-effectiveness aspects should to be taken into consideration, because it is important that the monitoring can be carried out over decades. The results in chapter 3.2 indicate that a monthly monitoring does not make sense. Only commonly used surveys 4-times a year ensure comparability on national and international levels. The relatively low numbers of items found per survey, suggests to carry out replica (two transects side by side) on most beaches, to increase the data density for source analysis.

The annual staff effort for the survey of one beach with replica ( 2 times $100 \mathrm{~m}$ profiles), 4 times a year always with 2 persons, including documentation, data entry and quality control is estimated to be 5-6 person days of $8 \mathrm{~h}$.

For the entire German Baltic coast, we suggest 14 beaches, based on our results and experiences as well as considering aspects like accessibility. The concrete beaches with coordinates and description are shown in Appendix 2. Beside the total field survey effort of about 80 days, the responsible authority has to spent an additional annual effort of estimated 80-100 days by for communication, training and coordinating of surveyor organisations; data transfer, input, documentation, quality control, database maintenance and improvement as well as data analysis, reporting and presentation for the Germany Baltic coast.

For the Lithuanian coast, two locations without replicas seem sufficient. More important than the concrete locations of sampling sites in Germany and Lithuania are methodological aspects. It needs to be ensured that staff is well trained with respect to field survey and determination of items and that the same persons carry out the survey at defined dates. To maintain a volunteer based survey system on many beaches 
makes sense as long as sufficient training (test sampling and item determination) and data quality management can be ensured.

In detail, methodological improvements and adaptations to the Baltic are required: A joint identification of items in the laboratory may improve data quality. Improved protocols and photo catalogues adapted to Baltic needs would be helpful. Problems and errors need to be reported to a central unit, to ensure ongoing methodological improvements. Only joint national and Baltic-wide databases can ensure an automatic data quality assessment especially for data collected by volunteers. These experiences support the recommendations of JRC (2013).

Even when involving volunteers, macro-litter beach monitoring causes considerable costs of labour, but other costs like laboratory analyses, equipment or shipping are negligible. JRC (2013) estimates the annual effort for running a monitoring at 4 beaches including all other costs, like data analysis, reporting to 55 person days. Taking into account, that the suggested German Baltic macro litter monitoring includes 14 instead of 4 beaches, our estimated total costs of 160 180 person-days are in a similar range.

\section{Conclusions}

The limited amount of suitable beaches (without regular cleaning), tourism/recreation as dominating litter source on all beaches increasing strong small-scale pollution gradients and a very high temporal and spatial variability of item abundances characterise the situation at the German Baltic coast. Therefore, we can conclude that the macro-litter beach monitoring method is less suitable for the Baltic, than for the North Sea/Atlantic region and apart from exceptions like Lithuania, can only serve as a complementary method in combination with others.

Even if we consider all data of the monitored Baltic German beaches ( $>30)$, the high spatio-temporal variability of data and the lack of sufficiently reliable descriptors to estimate litter amounts and composition for beaches that are not part of the monitoring, do not allow to estimate annual total litter amounts for the entire German Baltic coast. A spatial GIS based modelling approach may be useful, in this respect. Further, it is very likely that intensively used for recreational beaches will show the highest pollution, but are not suitable for official MSFD-monitoring because of beach cleanings. The macro-litter beach monitoring method avoids pollution hot-spots rather than focusing on them, but a focus on hotspots is required to reduce emissions and to develop suitable avoidance measures. This problem largely results from history, because beach litter surveys were mostly implemented to assess sea-based sources.
We need to assess whether implemented prevention measures show a positive effect on all beaches. Therefore, most important is the development and application of complementary methods that address other beach litter fractions, like micro- and meso-litter, are more flexible and robust towards disturbances, like beach cleanings, and can be applied at pollution hot-spots. A problem is that these litter size fractions provide less information about sources.

The very specific litter abundancies for each beach show that the definition of a general threshold (number of items per year) for marine macro-litter, defining a good status according to the MSFD, is not easily possible for German Baltic beaches. The same is true for reference values, describing a pre-industrial, historical situation at a beach. The high spatiotemporal variability would require a specific threshold for each beach. The variability of data does not allow a reliable assessment if a threshold has been met or not. Pollution sources in the Baltic are local and the definition of a threshold for each beach bears weaknesses. Even in case a threshold would be met, it would not be an indication of a generally improved state of the environment, but would only reflect local improvements. Alternative approaches are the definition of percentage decrease, but this is problematic because of high data variability.

Despite all subjectivity, the Matrix Scoring Technique (Tudor and Williams 2004) turned out to be suitably supporting method to receive a better insight into macrolitter sources. With $42 \%$ a relatively large share of all litter items could not be allocated to specific sources. A systematic further development and adaptation of the methodology to the Baltic, based on specific field experiments and new techniques, like mobile spectroscopic methods for plastics identification, should allow to improve its accuracy and to integrate the Matrix Scoring Technique into macro-litter monitoring approaches.

Flow and transport simulations are another suitable supporting method to get a better understanding of spatiotemporal processes and accumulation hot-spots. However, the present model considers only litter with a density, that is drifting with the surface flow. This needs to be extended to a larger variety of litter types. Only then a comparison with temporal high resolved data and a validation of the model simulations seems possible.

Acknowledgement This work was carried out within an UBA (Umweltbundesamt) project on marine litter (FKZ 371325 220) and was partly supported by project MikrOMIK, funded by the Leibniz Association (SAW-2014-IOW-2). This research would not have been possible without the beach litter data collected by a number of different institutions. Special thanks to EUCC - The Coastal Union Germany, Citizen of the Ocean network, Nature and Biodiversity Conservation Union Germany (NABU), South-East Rügen Biosphere Reserve, Regional School „Windland“ Altenkirchen, Vorpommern Boddenlandschaft National Park, Jasmund National Park, Usedom Nature Park, Jordsand Association. 


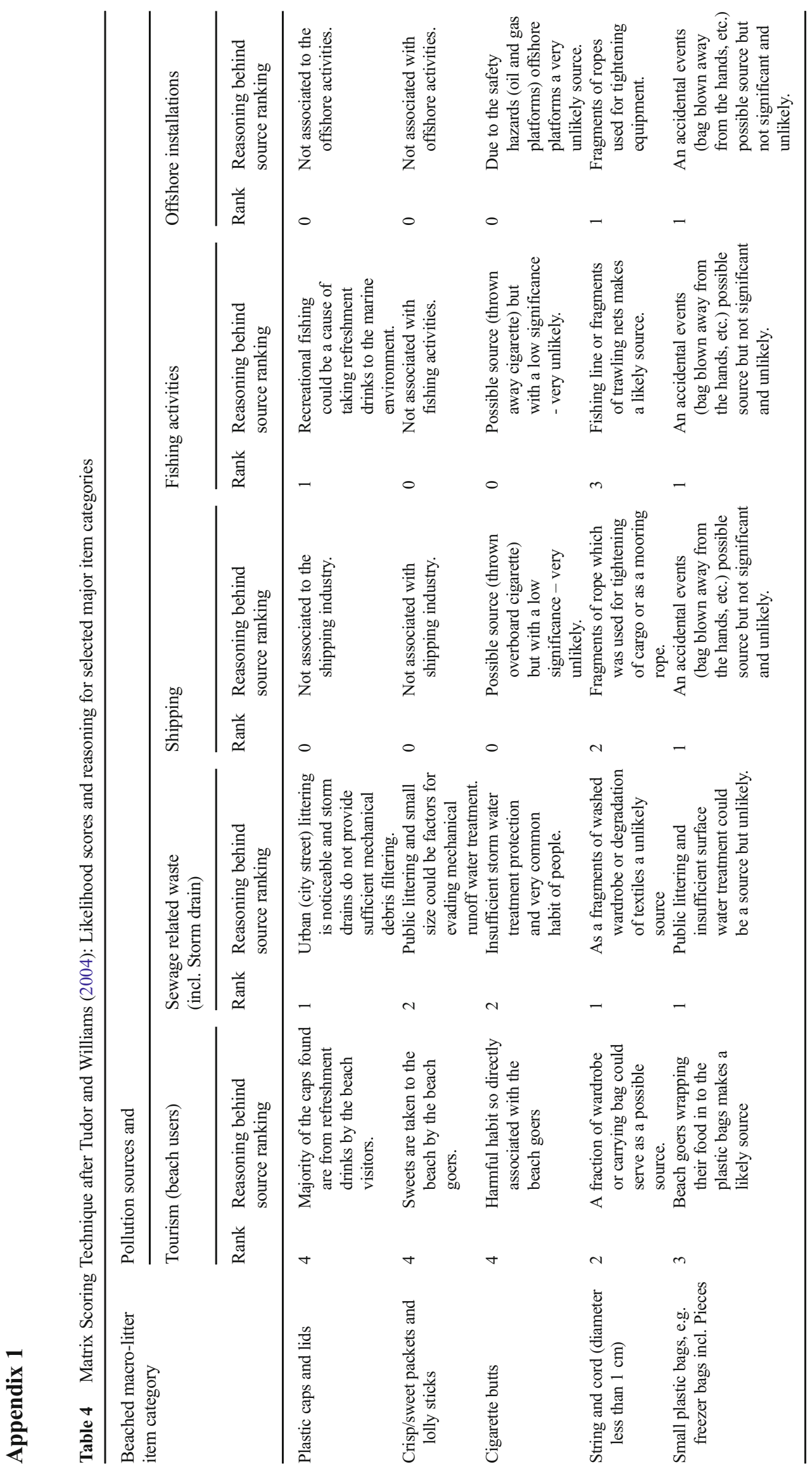




\section{Appendix 2}

Table 5 Suggestions of regular macro-litter sampling locations at the German Baltic coast within the MSFD monitoring and reporting

\begin{tabular}{llll}
\hline Name of the location & Potential surveyor & Geographic coordinates \\
\hline Federal state of Mecklenburg Vorpommern (Baltic coast, Germany): & & \\
Steinbeck östl. Kleinklützhöved & LUNG & $54^{\circ} 0^{\prime} 36.33^{\prime \prime} \mathrm{N}$ & $11^{\circ} 8^{\prime} 11.64^{\prime \prime} \mathrm{E}$ \\
Darß Weststrand Müllerweg & NPA VP & $54^{\circ} 25^{\prime} 41.84^{\prime \prime} \mathrm{N}$ & $12^{\circ} 28^{\prime} 20.47^{\prime \prime} \mathrm{E}$ \\
Zingst am Wasserweg & NPA VP & $54^{\circ} 26^{\prime} 23.28^{\prime \prime} \mathrm{N}$ & $12^{\circ} 49^{\prime} 2.00^{\prime \prime} \mathrm{E}$ \\
Varnkevitz westl. Höllenliet & Windland-Schule & $54^{\circ} 40^{\prime} 55.85^{\prime \prime} \mathrm{N}$ & $13^{\circ} 22^{\prime} 17.98^{\prime \prime} \mathrm{E}$ \\
Sellin an der Granitz (Nordostufer) & NABU Rügen & $54^{\circ} 23^{\prime} 30.92^{\prime \prime} \mathrm{N}$ & $13^{\circ} 41^{\prime} 2.38^{\prime \prime} \mathrm{E}$ \\
Greifswalder Oie nördl. Hafen & Verein Jordsand & $54^{\circ} 14^{\prime} 39.83^{\prime \prime} \mathrm{N}$ & $13^{\circ} 54^{\prime} 36.66^{\prime \prime} \mathrm{E}$ \\
Federal state of Schleswig-Holstein (Baltic coast, Germany): & & \\
Holnis & NABU & $54^{\circ} 52^{\prime} 8.72^{\prime \prime} \mathrm{N}$ & $9^{\circ} 36^{\prime} 9.29^{\prime \prime} \mathrm{E}$ \\
Fehmarn Wallnau & NABU Vogelreservat Wallnau & $54^{\circ} 28^{\prime} 44.15^{\prime \prime} \mathrm{N}$ & $11^{\circ} 0^{\prime} 39.38^{\prime \prime} \mathrm{E}$ \\
Fehmarn Krummsteert & $54^{\circ} 26^{\prime} 10.51^{\prime \prime} \mathrm{N}$ & $11^{\circ} 1^{\prime} 24.51^{\prime \prime} \mathrm{E}$ \\
Fehmarn Grüner Brink & NABU & $54^{\circ} 31^{\prime} 19.18^{\prime \prime} \mathrm{N}$ & $11^{\circ} 9^{\prime} 36.03^{\prime \prime} \mathrm{E}$ \\
Bottsand & NABU & $54^{\circ} 25^{\prime} 48.07^{\prime \prime} \mathrm{N}$ & $10^{\circ} 17^{\prime} 48.72^{\prime \prime} \mathrm{E}$ \\
Dummersdorfer Ufer & NABU & $53^{\circ} 54^{\prime} 51.73^{\prime \prime} \mathrm{N}$ & $10^{\circ} 51^{\prime} 36.00^{\prime \prime} \mathrm{E}$ \\
Geltinger Birk & Landschaftspflege Dummersd. & \\
Oehe Schleimünde & Ufer e.V. & $54^{\circ} 47^{\prime} 46.00^{\prime \prime} \mathrm{N}$ & $9^{\circ} 54^{\prime} 40.99^{\prime \prime} \mathrm{E}$ \\
\hline
\end{tabular}

Open Access This article is distributed under the terms of the Creative Commons Attribution 4.0 International License (http:// creativecommons.org/licenses/by/4.0/), which permits unrestricted use, distribution, and reproduction in any medium, provided you give appropriate credit to the original author(s) and the source, provide a link to the Creative Commons license, and indicate if changes were made.

\section{References}

Balčiūnas A, Blažauskas N (2014) Scale, origin and spatial distribution of marine litter pollution in the Lithuanian coastal zone of the Baltic Sea. Baltica 27(Special Issue):39-44

Bundesregierung (2011) Maritime Sicherheit in der Ostsee. Antwort der Bundesregierung auf die Kleine Anfrage der Abgeordneten Uwe Beckmeyer, Dr. Hans-Peter Bartels, Heinz-Joachim Barchmann, weiterer Abgeordneter und der Fraktion der SPD. Drucksache 17/ 5791. 26.05.2011

Burchard H, Bolding K (2002) GETM. A General Estuarine Transport Model. Scientific Documentation. Technical Report EUR 20253 EN European Commission. References 103, http://www.io-warnemuende. de/tl files/staff/burchard/pdf/papers/getm.pdf

Cadiou B, Pouline P, Dugué L (2011) Occurrence of marine debris in European shag's nests as indicator of marine pollution. Seabird Group 11th International Conference, 2-4 September 2011, Plymouth

Duhec AV, Jeanne RF, Maximenko N, Hafner J (2015) Composition and potential origin of marine debris stranded in the western Indian Ocean on remote Alphonse Island, Seychelles. Mar Pollut Bull 96: $76-86$

Gago J, Lahuerta F, Antelo P (2014) Characteristics (abundance, type and origin) of beach litter on the Galician coast (NW Spain) from 2001 to 2010. Sci Mar 78(1):125-134. doi:10.3989/scimar.03883.31B

Gräwe U, Wolff J-O (2010): Suspended particulate matter dynamics in a particle framework Environmental Fluid Mechanics 10
Gräwe U, Naumann M, Mohrholz V, Burchard H (2015a) Anatomizing one of the largest saltwater inflows into the Baltic Sea in December 2014. J Geophys Res Ocean 120:7676-7697

Gräwe U, Holtermann P, Klingbeil K, Burchard H (2015b) Advantages of vertically adaptive coordinates in numerical models of stratified shelf seas. Ocean Model 92:56-68

Hartwig E, Clemens T, Heckroth M (2007) Plastic debris as nesting material in a kittiwake-(Rissa tridactyla)-colony at the Jammerbugt, Northwest Denmark. Mar Pollut Bull 54:595-597

HELCOM (2008) Recommendation 29/2, Marine Litter within the Baltic Sea Region. http://www.helcom.fi/Recommendations/Rec\%2029-2. pdf. Accessed 21 Feb 2017

Jayasiri HB, Purushothaman CS, Vennila A (2013) Quantitative analysis of plastic debris on recreational beaches in Mumbai, India. Mar Pollut Bull 77:107-112

JRC (2010) Marine Strategy Framework Directive, Task Group 10 Report Marine litter. http://ec.europa.eu/environment/marine/pdf/9Task-Group-10.pdf. Accessed 21 Feb 2017

JRC (2013) Guidance on Monitoring of Marine Litter in European Seas. Online August $2014 \mathrm{http}: / /$ publications.jrc.ec.europa. eu/repository/bitstream/111111111/30681/1/lb-na-26113-en-n.pdf

Klingbeil K, Mohammadi-Aragh M, Gräwe U, Burchard H (2014) Quantification of spurious dissipation and mixing - discrete variance decay in a finite-volume framework. Ocean Model 81:49-64

Lippiatt S, Opfer S, Arthur C (2013): Marine Debris Monitoring and Assessment. NOAA Technical Memorandum NOS-OR\&R 46

MARLIN (2013) Final Report of Baltic Marine Litter Project MARLIN Litter Monitoring and Raising Awareness. Online August 2014 http://www.hsr.se/sites/default/files/marlin-baltic-marine-litter-report.pdf

Montevecchi WA (1991) Incidence and types of plastic in gannets' nests in the Northwest Atlantic. Can J Zool 69:295-297

Neumann D, Callies U, Matthies M (2014) Marine litter ensemble transport simulations in the southern North Sea. Mar Pollut Bull 86(1-2): 219-228

OSPAR (2010) Guideline for Monitoring Marine Litter on the Beaches in the OSPAR Maritime Area, ISBN 903631973 9, http://www.ospar. org/ospar-data/10-02e_beachlitter\%20guideline_english\%20only.pdf

Potemra JT (2012) Numerical modeling with application to tracking marine debris. Mar Pollut Bull 65:42-50 
Rosevelt C, Los Huertos M, Garza C, Nevins HM (2013) Marine debris in Central California: quantifying type and abundance of beach litter in Monterey Bay, CA. Mar Pollut Bull 71:299-306

Schulz M, Neumann D, Fleet D, Matthies M (2013) A multi-criteria evaluation system for marine litter pollution based on statistical analyses of OSPAR beach litter monitoring time series. Mar Environ Res 92:61-70

Schulz M, Krone R, Dederer G, Wätjen K, Matthies M (2015a) Comparative analysis of time series of marine litter surveyed on beaches and the seafloor in the southeastern North Sea. Mar Environ Res 106:61-67

Schulz M, Clemens T, Förster H, Harder T, Fleet D, Gaus S, Grave C, Flegel I, Schrey E, Hartwig E (2015b) Statistical analyses of the results of 25 years of beach litter surveys on the south-eastern North Sea coast. Mar Environ Res 109:21-27

Smith SDA, Markic A (2013) Estimates of marine debris accumulation on beaches are strongly affected by the temporal scale of sampling. PLoS One 8(12):e83694. doi:10.1371/journal.pone.0083694

Sonntag N (2009) Investigating a seabird hotspot: factors influencing the distribution of birds in the southern Baltic Sea. Dissertation, Forschungs- und Technologiezentrum Westküste (FTZ). Universität Kiel
Topçu EN, Tonay AM, Dede A, Öztürk AA, Öztürk B (2013) Origin and abundance of marine litter along sandy beaches of the Turkish western Black Sea coast. Mar Environ Res 85:21-28

Tudor DT, Williams AT (2004) Development of a 'matrix scoring technique' to determine litter sources at a Bristol Channel beach. J Coast Conserv 9:119-127

UNEP/IOC (2009) UNEP/IOC Guidance on Survey and Monitoring of Marine Litter. Online August 2014 http://www.unep. org/regionalseas/marinelitter/publications/docs/Marine_Litter Survey and Monitoring_Guidelines.pdf

Van Franeker JA, Blaize C, Danielsen J, Fairclough K, Gollan J, Guse N, Hansen P-L, Heubeck M, Jensen J-K, Le Guillou G, Olsen B, Olsen K-O, Pedersen J, Stienen EWM, Turner DM (2011) Monitoring plastic ingestion by the northern fulmar Fulmarus glacialis in the North Sea. Environ Pollut 159:2609-2615

Votier SC, Archibald K, Morgan G, Morgan L (2011) The use of plastic debris as nesting material by a colonial seabird and associated entanglement mortality. Mar Pollut Bull 62:168-172

Whiting SD (1998) Types and sources of marine debris in fog bay, northern Australia. Mar Pollut Bull 36:904-910

Williams AT, Tudor DT, Randerson P (2003) Beach litter sourcing in the Bristol Channel and Wales, U. K. Water Air Soil Pollut 143:387-408 